Article

\title{
Offshore Wind Farms as Potential Locations for Flat Oyster (Ostrea edulis) Restoration in the Dutch North Sea
}

\author{
Pauline Kamermans ${ }^{1, *}$, Brenda Walles ${ }^{1}$, Marloes Kraan ${ }^{1,2}$, Luca A. van Duren ${ }^{3}$, \\ Frank Kleissen ${ }^{3}$, Tom M. van der Have ${ }^{4}$, Aad C. Smaal ${ }^{5}$ and Marnix Poelman ${ }^{1}$ \\ 1 Wageningen Marine Research, Wageningen University and Research, P.O. Box 77, 4400 AB Yerseke, \\ The Netherlands; brenda.walles@wur.nl (B.W.); marloes.kraan@wur.nl (M.K.); \\ marnix.poelman@wur.nl (M.P.) \\ 2 Environmental Policy Group, Wageningen University and Research, P.O. Box 8130, 6700 EW Wageningen, \\ The Netherlands \\ 3 Deltares, P.O. Box 177, 2600 MH Delft, The Netherlands; luca.vanduren@deltares.nl (L.A.v.D.); \\ frank.kleissen@deltares.nl (F.K.) \\ 4 Bureau Waardenburg, P.O. Box 365, 4100 AJ Culemborg, The Netherlands; t.m.van.der.have@buwa.nl \\ 5 Aquaculture and Fisheries Department, Wageningen University and Research, P.O. Box 17 338, \\ 6700 AH Wageningen, The Netherlands; aad.smaal@wur.nl \\ * Correspondence: pauline.kamermans@wur.nl
}

Received: 29 August 2018; Accepted: 24 October 2018; Published: 30 October 2018

\begin{abstract}
The "Dutch Energy Agreement" motivates governments and industries to invest in renewable energy sources, of which offshore wind energy is one of the solutions to meet the agreed target of $16 \%$ of the total energy budget from renewable resources by 2023 . An option for the multi-use of wind farms is nature-inclusive building, in which the design and construction of wind farms make use of the potential for co-design with oyster bed restoration. This can support the government's ambitions, for the Dutch North Sea, to achieve biodiversity goals, restore ecosystem functions, and enhance ecosystem services, including future seafood production. For the recovery of flat oyster (Ostrea edulis) beds, knowledge is required about the conditions under which active restoration of this species in the North Sea can be successfully implemented. This paper gives a framework and presents results to determine suitability of wind farms for flat oyster restoration, and provides recommendations for pilot studies. Our analysis showed that a number of wind farms in the Dutch section of the North Sea are suitable locations for development of flat oyster beds. Combining oyster restoration and oyster culture, as a protein source, is a viable option worth investigating.
\end{abstract}

Keywords: Ostrea edulis; native oyster restoration; North Sea; site selection; pilot study; offshore wind farms

\section{Introduction}

The "Dutch Energy Agreement", a document by the Dutch government and dozens of organizations and interest groups, presents the energy ambitions and targets up until 2023 and beyond. This agreement motivates governments and industries to invest in renewable energy sources, of which offshore wind energy is one of the solutions to meet the agreed $16 \%$ increase in the share of renewable energy by 2023. Significant North Sea space is required to meet the future goals of the energy transition, resulting in competition between current users, such as exploitation of oil and gas, fisheries, nature, shipping, and the new wind farms. Current insights in multi-use options are still in an exploratory phase, and policies are currently developed to support the multi-use of space. 
Besides the goals set for energy arrangements, there is an increasing global demand for protein and carbohydrate sources. The world population is likely to grow up to 9 billion people by 2050, resulting in the need to provide proteins for all, of which fish and marine products can be part of [1]. Furthermore, alongside its contribution to protein intake, the value of fish is even stronger for poor consumers because of its micro-nutrient and lipid content [1]. This trend requires a more flexible food provision system and new sources. On the one hand, the current production, production methods, and value chains should be assessed, improved, and optimized. This needs to coincide with the arrangement of adapted locations and suitable space, as well as with an adequate governance strategy. On the other hand, production of food and proteins needs to expand and/or convert to alternative sources. Aquaculture is "projected to remain the fastest growing food commodity sector" [1]. As part of this development, aquaculture in open marine systems is seen as a potential large-scale expansion possibility [2,3]. The main reasons for global demand for seafood is the increase in world-population, the increase of consumption per capita, as well as the increase in income [1,4]. Because limits in the wild capture fisheries have been reached, with demand unable to be supported, aquaculture is considered the major future seafood contributor $[5,6]$.

Mariculture has a wide history in nearshore and inshore areas and estuarine environments. The physical conditions and the relatively easy accessibility of these areas are the driving forces behind their use. However, there are growing concerns about the impact on the environment $[7,8]$, and nearshore and inshore competition for space is setting limitations for the expansion or introduction of aquaculture $[9,10]$. Therefore, the "blue revolution" (the remarkably fast expansion of marine aquaculture and marine use in recent years) is set up to expand aquaculture practices in more exposed open sea and offshore areas. New technologies provide further impulse for this expansion. For example [11,12], investigated the potential of aquaculture for offshore seaweed and mussel farming in the Dutch North Sea.

Gerty [13] reported that the potential of marine aquaculture is demonstrated in many parts of the world. Worldwide the potential of development is far greater than the seafood demand, and expansion for space is not limited in many offshore locations. However, locally the options are not always directly suitable. The North Sea is a crowded and intensively used sea. Combinations of functions are therefore welcome. Currently, the potential for multi-use functions of offshore platforms, including wind farms, are under investigation worldwide $[14,15]$. One of the options is nature-inclusive construction, in which the design and construction of wind farms include the potential to enhance biodiversity and natural resources.

Until about a century ago, flat oyster beds constituted an important habitat in the North Sea. The flat oyster was a key species that once existed in the North Sea ecosystem, a fact that has almost disappeared from public memory. According to field surveys conducted in the 19th and early 20th century, the North Sea harbored substantial areas of oyster beds in that time (over 25,000 $\mathrm{km}^{2}$, [16] in $[17,18]$. However, by the end of the 19th century the flat oyster fishery became too intensive, which caused the oyster population to decline rapidly $[17,18]$. By the beginning of the 20th century, the oyster beds were already decimated [17]. Later, other types of bottom trawling fisheries also impacted on the remaining beds. Other reasons for the decimation are not documented. As a result, the oyster community, including related species, disappeared from the North Sea.

For the recovery of flat oyster (Ostrea edulis) beds, knowledge is required about the conditions under which active restoration of this species in the North Sea can be successfully implemented. This paper gives a framework and presents results to determine suitability of wind farms for flat oyster restoration, and provides recommendations for pilot studies. The information is used to support the marine spatial planning of wind farm and nature restoration.

\subsection{Flat Oyster Bed Ecosystem Services in the North Sea}

Several factors motivate flat oyster restoration in the North Sea. Flat oyster beds are a threatened species and habitat (OSPAR, European Union (EU) Habitat Directive, biogenic reefs, EU Red List 
of Species and Habitats). They once constituted a key element of a rich North Sea. Oyster beds are some of the most striking structures in soft-sediment environments, providing many ecosystem services, including the provision of habitat, which is important for biodiversity $[19,20]$, pelagic-benthic ecosystem coupling, shoreline stabilization, water quality regulation, and the enhancement of fishery production [21-23]. There is a lack of knowledge on the ecosystem services provided by deep-water flat oyster beds, as most studies have focused on the intertidal reefs of the Pacific oyster. Despite this, some mechanisms are assumed to be generic for both species and environments. [24], for example, demonstrated that the species facilitations function of the intertidal native European oyster bed is similar to the invasive Pacific oyster (C. gigas) reefs.

Beds of the European oyster Ostrea edulis function as a habitat for many species (Figure 1). Beds provide settlement substrate for epibenthic flora and fauna, food and shelter to mobile invertebrates (e.g., crab, lobster, and shrimps), and fish can use the beds as shelter (particularly in the juvenile stage) and spawning grounds (e.g., herring). The hard substrate, formed by the O. edulis shells, increases in time through recruitment and growth, harboring higher species diversity than non-living hard substrate [25].

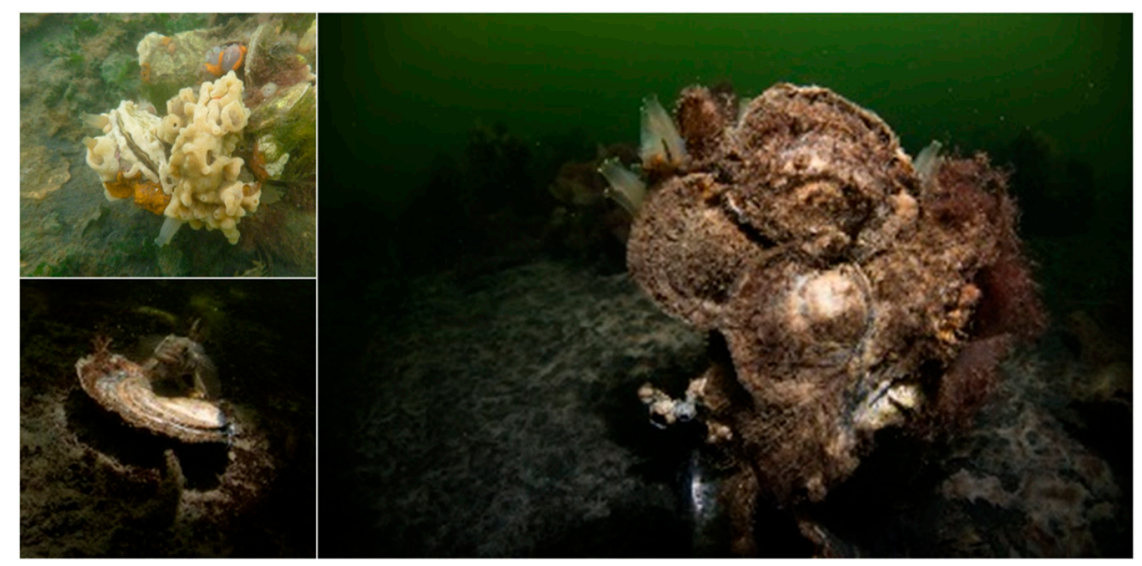

Figure 1. Shells of the European oyster Ostrea edulis provide substrate for epibenthic flora and fauna. Pictures by Youri van Es and Aad Smaal.

Oyster reefs, as ecosystem engineers, impact the benthic environment by altering the biogeochemical and physical properties of the sediment, affecting community composition, abundance, and species richness. As filter feeders, oysters enhance the pelagic-benthic ecosystem coupling through the production of fecal and pseudofecal deposits, followed by mineralization [26,27], which may stimulate phytoplankton turnover, enhancing primary production [28]. In addition, reefs of filter feeders can concentrate and trap organic matter, which fuel local food webs (Figure 2). Concentration of organic matter has been demonstrated for intertidal mixed blue mussel (Mytilus edulis) and Pacific oyster reefs [29], deep reef structures of the cold-water coral Lophelia pertusa [30], and tubeworm Lanice conchilega reefs [31]. De Smet et al. (2016) [31] demonstrated that L. conchilega can significantly concentrate and trap organic matter, produced in an area no less than 15 times the reef area, within their reef food web, resulting in a higher macrofaunal biomass and a more diverse food web than in the absence of the reef.

Large beds of bivalves can also have a major effect on the local fine sediment dynamics [32,33]. The large expanses of oyster beds in the 19th century must have had a large-scale effect on turbidity in the North Sea. The area of the old "oyster grounds" is characterized by relatively fine sediment [34], which, under high wave conditions, can resuspend into the water column affecting light penetration. It is to be expected that the presence of $25,000 \mathrm{~km}^{2}$ of oyster bed has affected these processes significantly. To what extent the changes in light penetration may have also affected local primary production is unknown. 

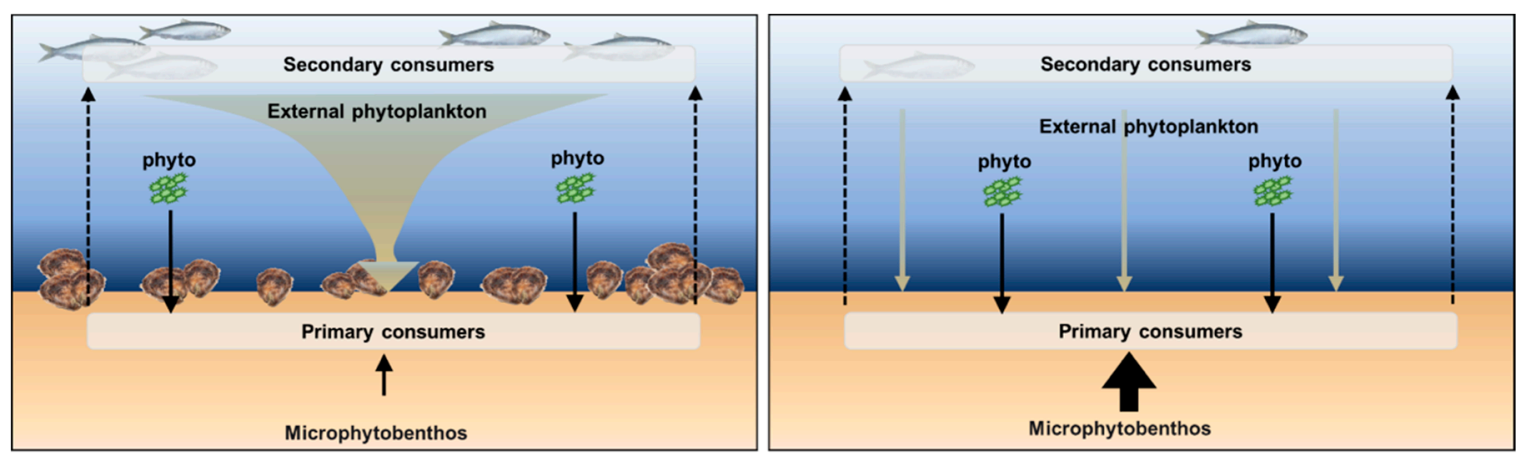

Figure 2. In the presence of the filter feeder Ostrea edulis, in situ-produced and laterally advected external phytoplankton dominate the carbon input into the bed, supporting a diverse-bed food web. In bare sand areas, the carbon input is much lower and mainly based on in situ primary production by microphytobenthos. Figure adapted from [31] De Smet et al. (2016).

Habitat formed by the oysters, combined with biodeposition, increases prey abundance, which is the driving force for enhanced fish production. [22] quantitatively estimated enhanced fish and mobile invertebrate production by oyster reefs. In the Gulf of Mexico, gross production was increased with $397 \mathrm{~g} \mathrm{~m}^{-2}$ year $^{-1}$ in the presence of oyster reefs [22]. Korringa (1954)] [35] reported about 250 species living in association with or on oyster beds. Hence, restoration would provide opportunities for ecosystem services, such as the commercial exploitation of fish and mobile invertebrates, as well as flat oysters themselves; provided that exploitation methods are developed that leave the flat oyster beds intact. As a consequence, the loss of oyster beds leads to a less productive and less diverse ecosystem and the loss of ecosystem services. In the Wadden Sea, the disappearance of the flat oyster beds resulted in a less diverse and productive mudflat ecosystem [36].

\subsection{Policy}

Restoring oyster beds will contribute to fulfil Dutch obligations, following from the Marine Strategy Framework Directive (MSFD). The recovery of natural hard substrates, including flat oyster beds, is an objective stated in the policy documents: Nature Ambition Large Water Bodies [37]; and the Implementation Agenda Natural Capital [38], under the title of shellfish beds in general; and in recent OSPAR recommendations (OSPAR, 2013). Sustainable energy supply, robust nature, and climate proof food supply are part of the Dutch Development Strategy for the North Sea (Noordzee 2050 Gebiedsagenda), and can potentially be realized with flat oyster restoration in wind farms.

Based on the European Common Fisheries Policy (CFP), a National Strategic Aquaculture Plan 2014-2020 has been described for the stimulation of aquaculture in the Netherlands. Among the prospects, the multi-use of space and offshore aquaculture have been identified as potentials for development.

\subsection{Food and Nutrition Security}

The utilization of the ocean for food is not a new development. Fish and aquatic products are long since the most traded food commodity in the world, whereby many seafood markets are global markets (https:/ / www.wto.org/english/res_e/reser_e/ersd201003_e.htm). In the last couple of years, attention to fish and aquaculture products, and the contribution they make to food and nutrition security, has grown $[1,39,40]$. In particular, special attention has been given to the contribution of small-scale fisheries [41-43] and the importance of (small) fish for feeding the poor [44,45]. Furthermore, in Europe, attention to the contribution of fish and aquatic products for food security has risen, mainly as part of what has been called "blue growth". The EU focusses on aquaculture when discussing blue growth, as catches in fisheries are regarded as stabilized. The EU is currently the fourth largest fish producer, after China, Indonesia, and India, and the largest trader (in value) of fishery and aquaculture 
products in the world. Accordingly, the EU has quite an impact on fish trade and production (European Market Observatory for Fisheries and Aquaculture Products EUMOFA). It also is the largest importer of fish products, buying $60 \%$ of the fish and aquaculture products consumed from other countries in the world (https:/ / www.euractiv.com/section/global-europe/opinion/closing-the-net-the-eumust-step-up-enforcement-of-seafood-import-controls/). Although, by doing so, the EU contributes, indirectly, to the food security of people elsewhere in the world whose livelihoods rely on fisheries, aquaculture, and trade. Due to the rising prices of seafood and the EU's higher financial power, the EU will eventually (and has already in some places (https:/ / www.pri.org/stories/2018-03-30/senegalesewomen-turn-exporting-fish-spite-local-shortages)), by safeguarding its own food security, impact on the direct food security of people in other countries [46]. Thus, the more the EU can produce itself, the better.

There are a couple of advantages of fish and aquatic products for food and protein, compared to other sources, in terms of ecological impact: Fish and aquatic products have a relatively high energy intensity compared to other food items [47]; the environmental costs, in terms of water use, fertilizer use, pesticide use, antibiotic use, and soil loss, as well as greenhouse gasses per $\mathrm{kg}$, are much lower for marine resourced food compared to dairy and meat [48]; and bivalves show a reduction of eutrophication ( $\mathrm{kg} \mathrm{PO}_{4}$ equivalent) compared to terrestrial derived meat and crops [49] (Hall et al., 2011). In terms of impacting biodiversity, [48] has argued that capture fisheries are sustained by maintaining semi-natural ecosystems, whereas agriculture relies on replacing natural ecosystems with highly productive exotic species, and aquaculture falls somewhere in between (https:/ / rayhblog.files.wordpress.com/2012/10/hilborn-world-fisheries-congress.pdf). Thus, when seeking opportunities to increase production of food, many turn to the ocean. It has also been established that, until now, mostly the top of the aquatic trophic pyramid has been harvested, which in fact is inefficient and less sustainable [50]. We could make much more use of the food potential of the ocean if we also, but not solely, consume fish and marine products at lower levels in the food chain. Flat oysters currently have a very high market value, due to the relatively low supply. If restoration programs become a success, in terms of growth, survival, and reproduction of oyster beds, the return of direct or indirect commercial exploitation may become possible. Currently an estimated $3000 \mathrm{~km}^{2}$ of wind farm area is accommodated for wind farm production (up to 2023). If $0.1 \%$ of this area could be used for oyster restoration, in combination with oyster production, a total of 300 ha is then available for restoration in combination with food production (current production area is $\sim 2.000$ ha in The Netherlands).

\subsection{Wind Farm Suitability}

In September 2014, the Dutch government designated three areas for the development of offshore wind farms over the years to come: Borssele, Noord-Holland, and Zuid-Holland (Figure 3). In the North Sea 2050 Spatial Agenda, the Ministries of Economic Affairs and Infrastructure and the Environment expressed their ambition for the combined use of offshore space. This is included in the environmental regulations and design regulations of the Wind Farm Site Decisions for next generation wind farms. More specifically, the Ministry of Economic Affairs stated their wish to establish whether the areas recently designated as offshore wind farm sites offer opportunities for the development of flat oyster beds. The fact that wind farms are in the current regulatory framework, free from seabed-disturbing activities, is regarded as a major precondition for the restoration of flat oyster beds [17,51]. Oyster bed restoration appears to be a viable option to support these ambitions in the Dutch North Sea, to simultaneously achieve biodiversity goals and restore and enhance ecosystem services, including future seafood production. 


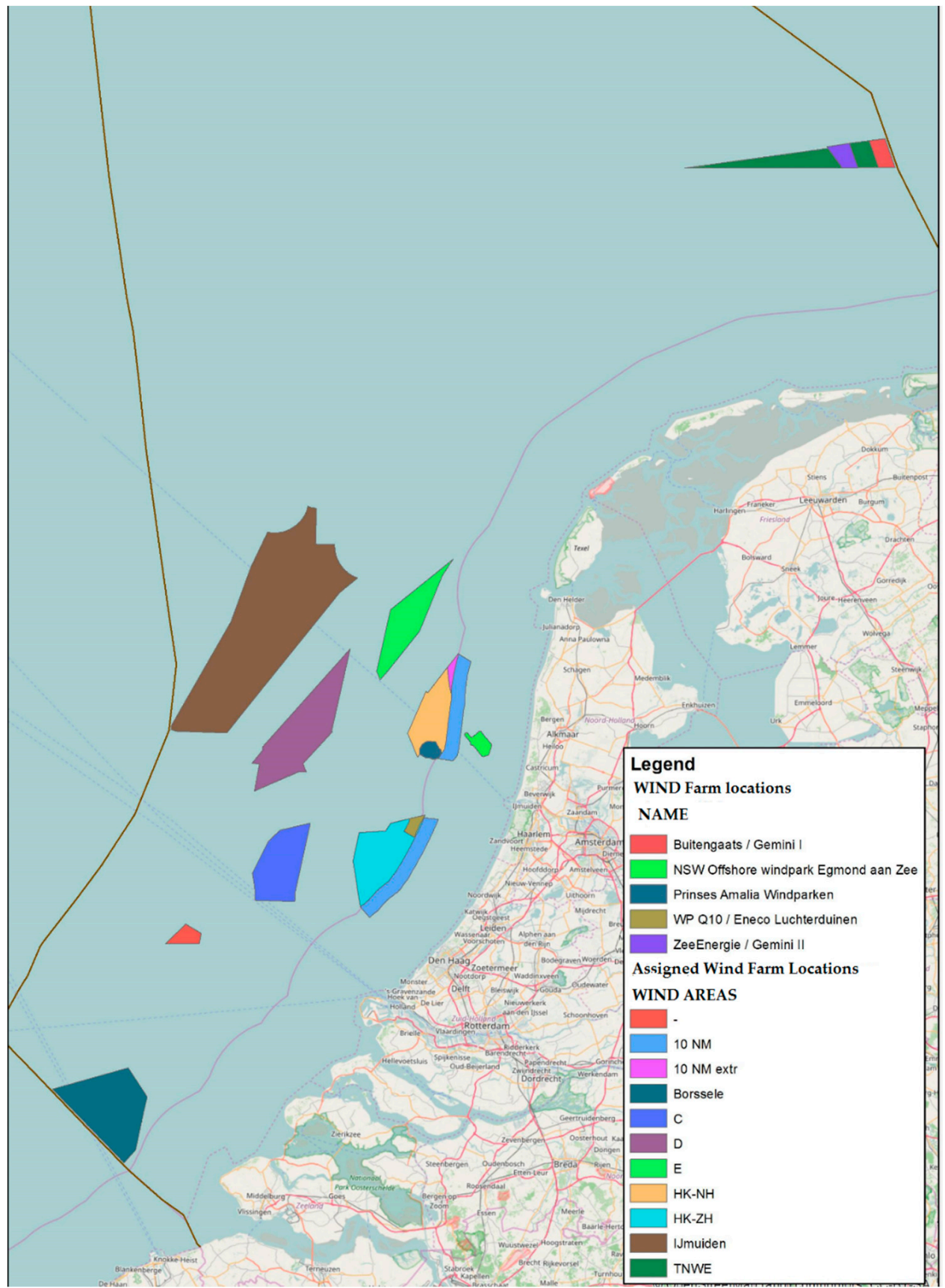

Figure 3. Locations of existing and planned wind farms in the Dutch section of the North Sea (DSC: Dutch Continental Shelf). The present study focusses on Borssele, Buitengaat/Gemini, offshore wind farm Egmond aan Zee (OWEZ), Dutch coast South and North (HK-NH, HK-ZH), Luchterduinen, Princes Amalia, and Zee-Energie. These wind farms are either in operation or are soon to be realized from [52].

Current conditions may favor the return of the flat oyster in the North Sea. The flat oyster has survived in estuaries around the North Sea (e.g., Limfjorden in Denmark, Lake Grevelingen and Oosterschelde in the Netherlands, plus various inlets on the coast of the British Isles, Norway, and Sweden). Recent records of individuals on shipwrecks, buoys, and marine wind farms in the North Sea show that it can still survive, reproduce, and disperse in the open sea [53]. Newly installed marine protected areas, wind farms, and offshore installations could provide sheltered areas that are free from bottom trawling fisheries. Yet, without human assistance the oyster beds may not return 
on a large scale. In the southern North Sea, the sea floor consists mainly of sand and silt, whereas rocks are uncommon. Oyster larvae have a limited dispersal range and need hard substrate to settle on [54,55], but without oysters, very little natural hard substrate has remained on the North Sea floor. So, once the oyster beds are gone, they will probably not return on their own because the source populations are too distant, even if the conditions are favorable. For the recovery of the flat oyster beds, knowledge of the conditions under which the active restoration of this species in the North Sea can be successfully implemented is required. To determine suitability of wind farms for flat oyster restoration we developed a framework, which considered the life history and habitat preferences of the species (Figure 4).

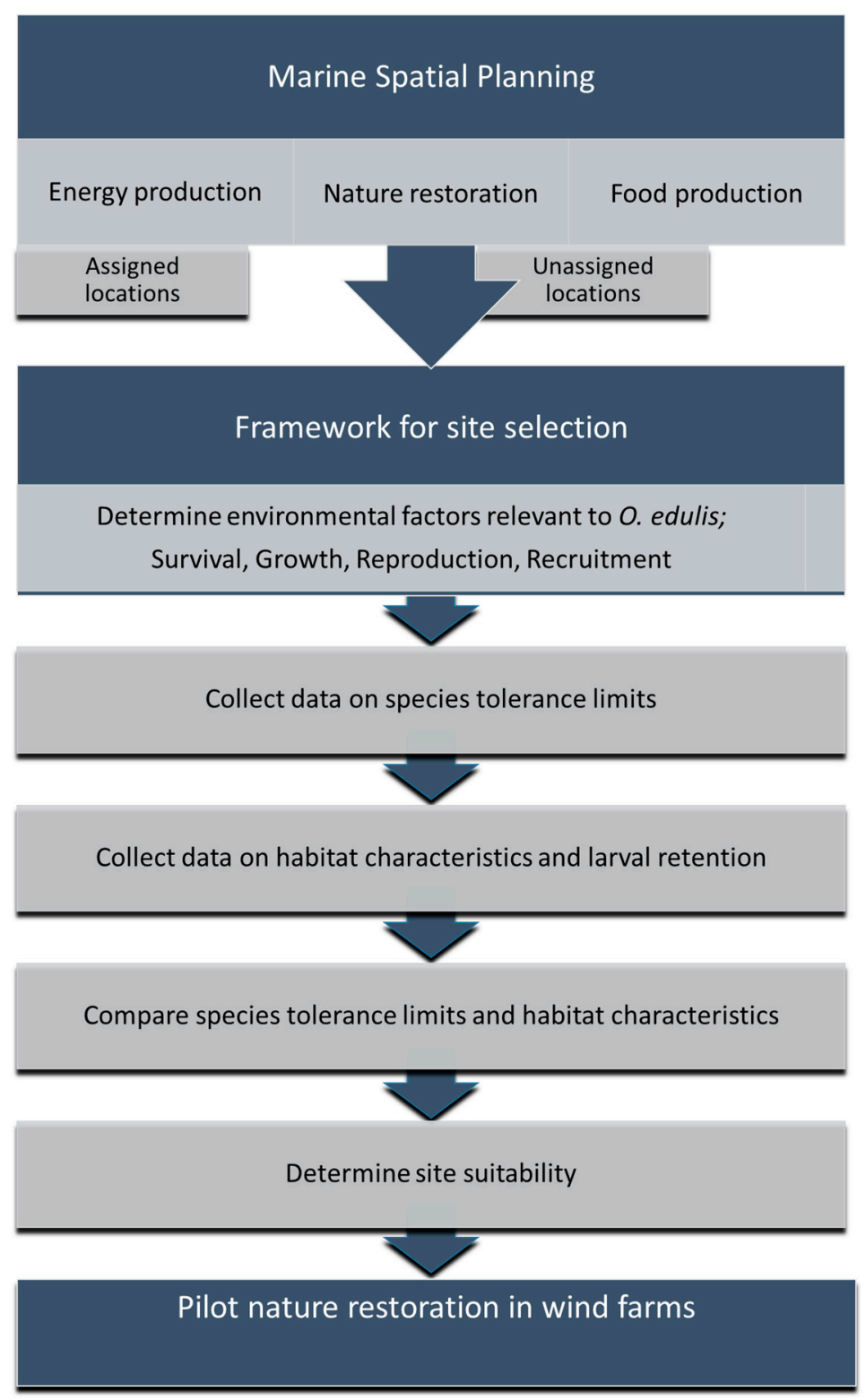

Figure 4. Schematic overview of the framework for site selection applied in the marine spatial planning of nature restoration, with special application of Ostrea edulis in wind farms.

\subsection{Life History}

Mature flat oysters can switch between sexes to be male or female [56]. Generally, flat oysters start as males and become females as they grow older. Older oysters can spawn twice during one season, once as a male and once as a female. Sperm cells, clustered in spermatozeugmata [57], are 
expelled through the exhalant siphon. Eggs remain in the mantle cavity of the female, where they are fertilized and develop into larvae with two shells in a period of one to two weeks. When they are released, the shell length of the larvae is 170-190 $\mu \mathrm{m}$. During their free-swimming stage (another 8-30 days: [58] the length increases to 290-360 $\mu \mathrm{m}$. Metamorphosis, from swimming larvae into sessile spat, depends on food availability for the larvae. Settlement occurs when a suitable location is detected. A drop of cement is produced and the left valve is glued to the surface. As a result of the relative short free-swimming stage, compared to other bivalve species, the dispersal distance of O. edulis is limited (on average $1 \mathrm{~km}$ [59]), although longer distances are occasionally possible during favorable conditions (up to more than $10 \mathrm{~km} \mathrm{[60]).} \mathrm{Oyster} \mathrm{spat} \mathrm{settles} \mathrm{on} \mathrm{hard} \mathrm{substrates,} \mathrm{such} \mathrm{as} \mathrm{stones,} \mathrm{shell}$ fragments, or oyster shells. They adhere or fix themselves to the substrate and do not disperse further. For spat collection, calcified tiles have been employed in many areas and are still in use in Arcachon Bay (France). Oyster shells in existing oyster beds are a preferred settling substrate for oyster spat. Oyster bed development is therefore a self-reinforcing process, due to the positive feedback of existing oysters on successful recruitment and settlement (e.g., Eastern oyster [61]). It implies that oyster beds have a critical mass below which recruitment may fail, due to limited substrate availability in relation to the number of larvae produced $[60,62]$.

\section{Materials and Methods}

The conditions for the long-term development of a flat oyster bed were largely determined by four life-history variables: Survival, growth, reproduction, and recruitment. Reproduction referred to the capacity to produce larvae; recruitment denoted the successful settlement of larvae in a specific site. These four variables were influenced by a range of abiotic and biotic factors, which are listed in Table 1. Survival depended on environmental factors such as large- and small-scale sea bed dynamics, oxygen content, salinity, and predation. Growth was mainly determined by phytoplankton and the concentration of suspended particles. Reproduction required a parent population in suitable age classes, and the right water temperature for gonadal development and spawning. Recruitment depended on water temperature, the quantity of larvae in a specific area, and the presence of suitable substrate for settlement. Recruitment was determined by the size of the parent population that produced the larvae, and served as larval settlement substrate, and by the water motion that determined larval retention in a specific area (see also $[63,64])$.

Table 1. Environmental factors, relevant to the various life-history processes of $O$. edulis, used as site selection criteria. The symbol (+) indicates a positive effect and (-) a negative effect.

\begin{tabular}{lcccc} 
& Survival & Growth & Reproduction & Recruitment \\
\hline Sea bed shear stress & - & & & \\
Sea bed motion & - & & \\
Concentration of suspended particles & & - & + & \\
Larval retention & & & + \\
Coarse sediment & & & \\
\hline
\end{tabular}

Tolerance ranges for abiotic and biotic environmental factors were derived from the literature to evaluate the suitability of already present and planned wind farm areas in the Dutch North Sea for flat oysters (Table 2). The wind farms under study were within the limits for the factors: Salinity, water depth, water temperature, current velocity, food supply, and oxygen concentration [52]. The selection criteria used were: Sea bed motion, bed shear stress, sediment composition, type of substrate, concentration of suspended particles, and rate of larval dispersal and retention. Information on the historical range of flat oysters in the North Sea (e.g., $[16,17,51])$ was used as an extra "habitat suitability indicator" (Figure 5). 
Table 2. Tolerance range and optimum of O. edulis for abiotic and biotic environmental factors. Adapted from [65].

\begin{tabular}{|c|c|c|c|c|}
\hline Environmental Factor & Response Variable & Range & Optimum & Reference \\
\hline \multirow{7}{*}{ Temperature $\left({ }^{\circ} \mathrm{C}\right)$} & Survival adults & $<30$ & & [66] \\
\hline & \multirow{2}{*}{ Growth adults } & $6-19$ & $7-14$ & [66-68] \\
\hline & & & 17 & [69] \\
\hline & Gonad development & $7-14$ & & [68] \\
\hline & $\begin{array}{l}\text { Survival and growth } \\
\text { larvae }\end{array}$ & $10-31$ & $25-27$ & [70] \\
\hline & Spat fall & $>18.5$ & & [71] \\
\hline & Survival spat & $>3$ & & {$[72]$} \\
\hline \multirow[t]{2}{*}{ Salinity (PSU) } & $\begin{array}{l}\text { Survival and growth } \\
\text { larvae }\end{array}$ & $20-39.5$ & $25-35$ & [73] \\
\hline & Growth adults & $>19$ & & [74] \\
\hline Water depth (m) & Survival adults & $<-80$ & & [75] \\
\hline Current velocity (m/s) & Survival adults & $<0.25$ & 0.03 & [76] \\
\hline Sea bed motion (cm/day) & Survival spat and adults & & $<0.8$ & [77] \\
\hline Sediment composition & Survival adults & & $\begin{array}{l}\text { Firm silty sand or silty } \\
\text { gravel with shells and stones }\end{array}$ & [78] \\
\hline $\begin{array}{l}\text { Suspended matter } \\
\text { concentration }(\mathrm{mg} / \mathrm{L})\end{array}$ & Food intake & $<90$ & & {$[79,80]$} \\
\hline Food supply (chla ug/L) & Gonad development & 1.68 & & [81] \\
\hline Oxygen concentration $(\mathrm{mg} / \mathrm{L})$ & Survival adults & $>0.5$ & & [82] \\
\hline
\end{tabular}

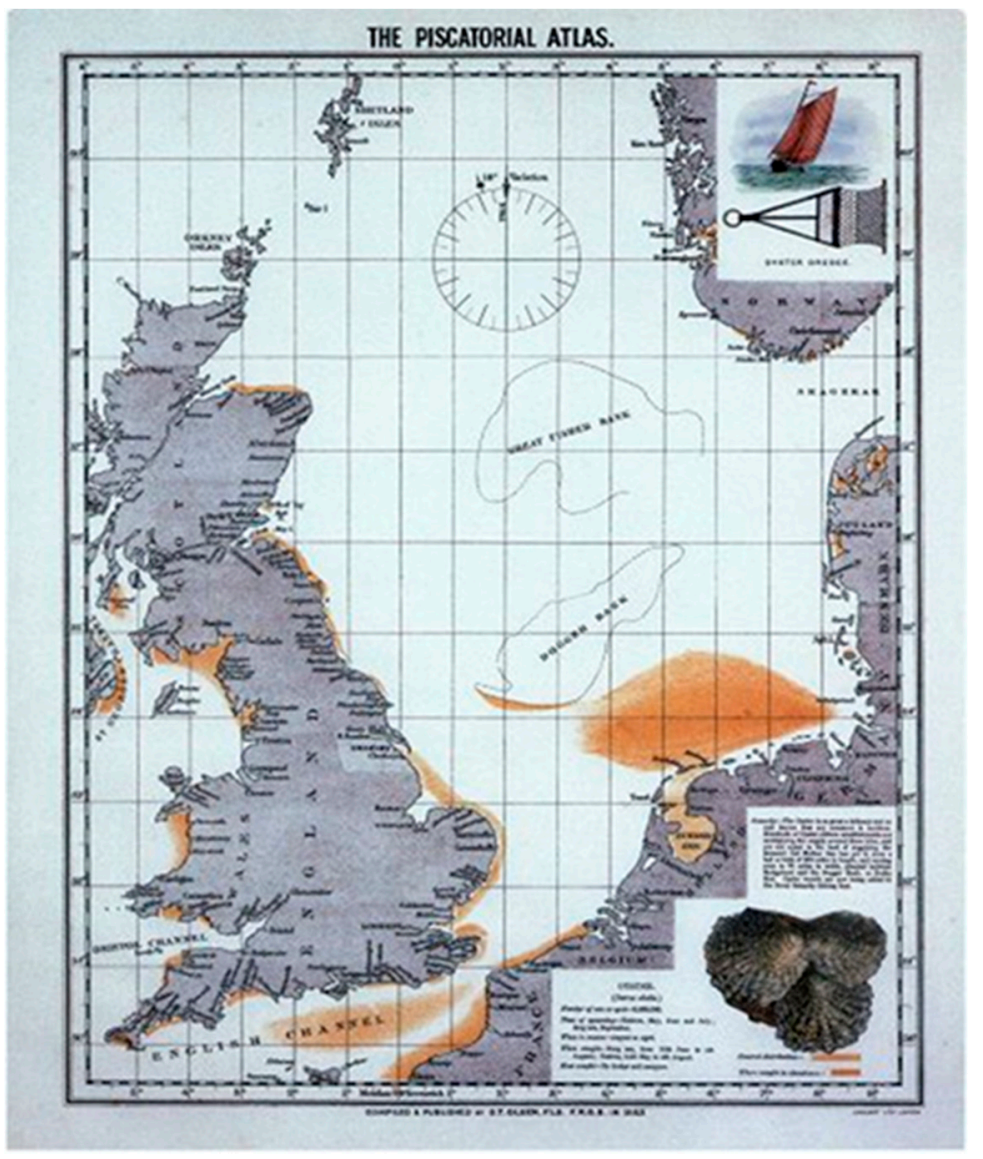

Figure 5. Map from Olsen's Piscatorial Atlas [16], with the oyster range represented in brown. 


\subsection{Sea Bed Motion and Bed Shear Stress}

Seabed dynamics can be described on different levels of scale. Therefore, a distinction was made between bed mobility morphodynamics, which concerns bed dynamics on a larger scale, and bed shear stress, as a measure of the force exerted by currents and waves on the bed. Bed shear stress is the driving force for the formation of sand waves [83-85]. It also has a direct influence on the settlement probability of shellfish larvae [86-88], as well as on the stability of the substrate on which they settle. The threshold is determined by sediment grain size, sediment density, and the influence of biota on sediment cohesion [89,90]. In a laboratory experiment, Grant et al. [77] demonstrated that low concentrations of suspended sediment, when swirled up $0.1 \mathrm{~cm} /$ day, can contribute to nutrient intake and, as such, have a positive effect on the growth speed of $O$. edulis, but that sediment churned up to $0.8 \mathrm{~cm}$ per day reduces growth. Tolerance of sea bed motion of up to $0.8 \mathrm{~cm} /$ day was therefore assumed in this study.

The southern North Sea, and particularly the Dutch continental shelf, is characterized by the occurrence of sand waves [91,92]. These features can range in height from less than $1.5 \mathrm{~m}$ up to $10 \mathrm{~m}$, and can have a wave length of 100 to $1000 \mathrm{~m}$. Under the influence of residual currents and waves, these waves can move over the bed surface of the North Sea with speeds up to several meters per year [93]. Although the average annual movement of sand waves is generally less than $0.8 \mathrm{~cm} /$ day, movement is not constant throughout the year and is often mediated by strong wave conditions. Many areas with migrating sand waves will, therefore, regularly experience sedimentation or erosion speeds that exceed the tolerance levels of flat oyster beds. Figure 6 shows the sea bed structure and sea bed motion features of the North Sea, as derived from the North Sea Atlas [94]. The effect of waves tends to be the most powerful in shallow waters. In deep waters, waves do not reach the seabed. Wave energy is often expressed as orbital velocity: the velocity of water just above the seabed caused by waves. The extent to which wave energy reaches the seabed depends on the height of the waves and the depth of the water. Waves are lower in coastal waters, but because these waters are shallow the orbital velocity is high. Offshore waves are higher, but under normal conditions their effect only reaches the seabed in shallower areas (such as the Dogger Bank). Orbital velocity and current velocity were both taken into account in the Delft 3D model of the Southern North Sea, often used to calculate fine sediment dynamics $[95,96]$. Comparison with the historical distribution of O. edulis (Figure 5) allowed us to assume that areas where sea bed shear stress was less than $0.6 \mathrm{~N} / \mathrm{m}^{2}$ were to be deemed suitable for the development of flat oyster beds. Sea bed shear stress levels are presented in Figure 7. 


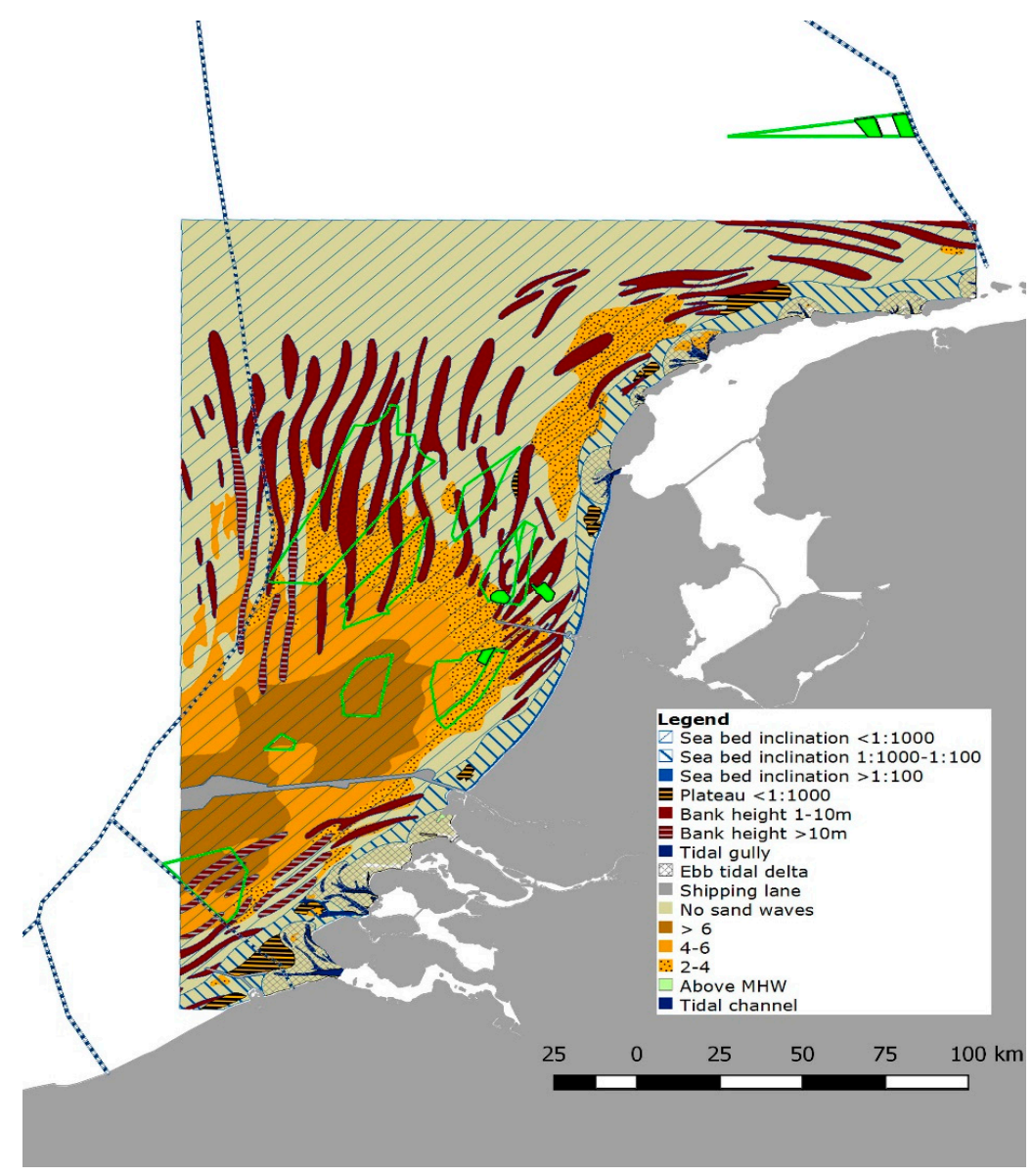

Figure 6. Sea bed structure and motion (source: North Sea Atlas, [95]), and wind farm sites in the Dutch section of the North Sea.

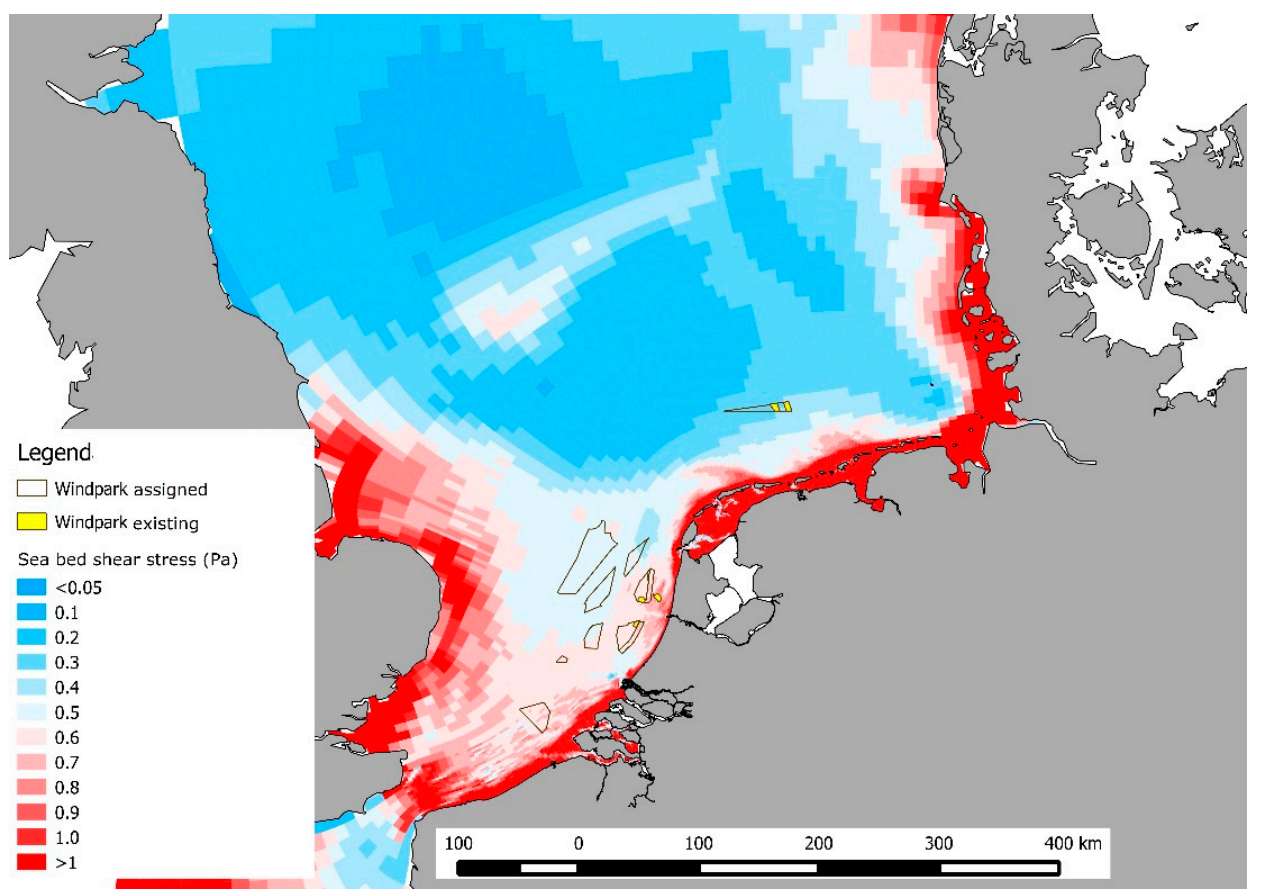

Figure 7. Average sea bed shear stress (in Pascal) in the North Sea, with combined effects of currents and waves. Wind farm sites are indicated. 


\subsection{Concentration of Suspended Particles and Sediment Composition}

The concentration of suspended particles is an important factor in oyster growth. Oysters filter suspended matter from the water; this includes phytoplankton, detritus, and inorganic matter. The oysters use the phytoplankton to fuel their growth, but they have no use for the inorganic material in their metabolism. Higher concentrations of inorganic material will reduce the oysters' capacity for growth. This applies to most filter feeders, including flat oysters (e.g., [97]). Experiments have confirmed that suspended particle concentration levels in excess of $90 \mathrm{mg} / \mathrm{L}$ strongly inhibit growth in Pacific oysters (Crassostrea gigas) [80]. To our knowledge, no such experiments have been performed for European oysters. Measurements in a field set-up by [98] have shown that the total concentration of suspended matter just above the seabed $(60 \mathrm{mg} / \mathrm{L})$ is significantly higher than $80 \mathrm{~cm}$ above the seabed $(40 \mathrm{mg} / \mathrm{L})$. This resulted in significantly lower filtration rates for O. edulis, although no significant effect was found on the condition of the oysters after 15 months. Concentration of suspended particles near the seabed was obtained from model calculations [96] and are presented in Figure 8.

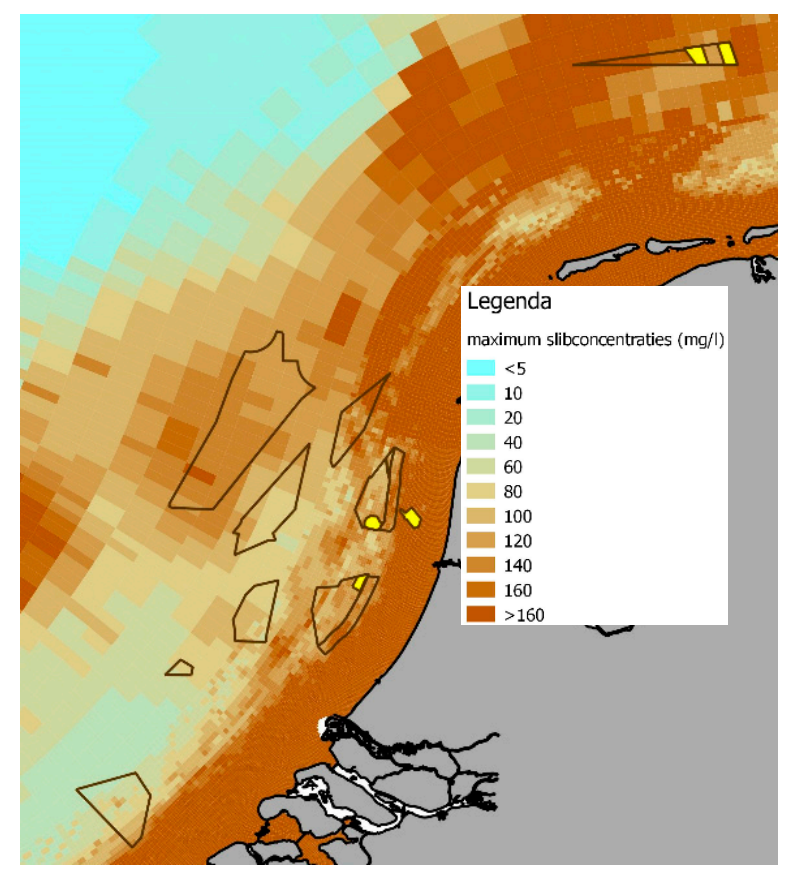

Figure 8. Maximum concentrations of inorganic suspended particles (mg/L) near the seabed in Dutch coastal waters, based on model simulation data. Wind farm sites are indicated.

Sediment composition is important as it determines substrate suitability for recruitment. First of all, shells and existing oyster beds will promote recruitment. In the absence of shells and oyster beds, sediment grain size is the most commonly used parameter. Sediment grain size is easy to measure. Spatial patterns in the range of shellfish often correlate with sediment grain size, but there is little evidence that this is the primary factor; other factors that co-vary with grain size are probably far more important [99]. Water motion can have an impact on sediment composition because heavy particles settle sooner than light ones. This is why silt tends to accumulate in sheltered spots, whereas coarser sediment particles are found in exposed areas. As a rule, grain size varies according to the average local current. [100] made a reconstruction of sediment composition along the Belgian coast, as it was a hundred years ago, based on the results of the Gilson surveys of 1899 to 1914 . In their reconstruction, the seabed that accommodated extensive oyster beds before 1860 was described as follows: A heterogeneous gravel field partially covered by a thin layer $(<15 \mathrm{~cm})$ of sand through which bits of stone protruded. [101] studied factors that could explain the dispersal of Olympia oysters (Ostrea lurida) in an estuary in California. Burial under a layer of fine sediment impeded the oysters' survival on small hard substrates. In areas with large amounts of silt, the oysters could only be found on large 
rocks. In the northwestern part of the Mediterranean, oyster growth on shipwrecks is dominated by Ostrea edulis [102]. Based on this dispersal data, coarse sand (grain size $>210 \mu \mathrm{m}$ ) was classified as unsuitable, fine sand $(>63 \mu \mathrm{m})$ as moderately suitable, and firm silty sand, or silty gravel with shells and stones (not defined in terms of grain size), was considered suitable for oyster growth [78]. Seabed structure is presented in Figure 8.

\subsection{Food Availability}

Growth and survival of adult and larval oysters clearly depends on food supply. For benthic filter feeders, food availability is driven by primary production as well as by transport (i.e., hydrodynamics). Even in areas with very high productivity, stratification can limit the access of benthic filter feeders to food supply $[103,104]$. The current wind farms, and the current potential wind farm areas, are in areas relatively close to the coast with large nutrient input and, hence, high levels of primary production. Additionally, in these areas, water is not stratified for prolonged periods of time, apart from close to the western coast of the Netherlands, where the fresh water plume from the rivers Rhine and Meuse have an influence [105]. However, these areas are shallow and highly productive. In the locations under investigation in this study, food supply as well as oxygen depletion were not limiting for the formation of oyster beds, although there may be limits on the carrying capacity of wind farm sites for large beds. Other parts of the North Sea are characterized by prolonged periods of stratification [105], which often coincide with oxygen depletion $[106,107]$. For these locations food availability as well as oxygen dynamics need to be considered specifically.

\subsection{Larval Dispersal and Retention}

For an estimate of potential oyster larvae dispersal from various locations and the retention rate within a certain area, a particle dispersal model was used (with the particles representing the larvae) that was driven by water motion data from the Delft3D-FLOW model $[95,108]$. The three-dimensional water motion was derived from the ZUNO-DD model [96]. Hydrodynamic data were available for the years 2003 through 2011 on the following features: Water levels, current velocity, water temperature, and salinity. The forcing functions for simulations, using the hydrodynamic model, were based on actual data, such as river outflows, water temperature, and wind data. Because this data covered a period of nine years, it covered the annual and inter-variability in hydrodynamic conditions. In this study, the larvae were modelled as passive particles. The transport of these particles was driven by water motion and by dispersal and diffusion processes. In the model, the age at which the larvae settled was assumed to be ten days from the moment the larvae leave the mother oyster [109]. There was no mortality until then. Larvae that are less than ten days old were unable to settle. Larvae were removed from the model as soon as they were more than ten days old, and they played no further role in the simulation. The particles entered into the model in a way that reflected data from actual larval counts during the season [110], with the release of larvae from the middle of June to the middle of August, and highest concentrations in the middle of July. The model did not present absolute concentration figures, but offered proportional figures of larval concentration relative to the total number of larvae generated in a specific period (Figure 9). The dispersal maps presented a picture of larval dispersal in relative concentrations over the months June-August. Using colors, ranging from dark green to yellow, to represent decreasing larval concentration levels, the maps showed that larval retention in Borssele and the two northerly wind farms, Buitengaats and Zee-Energie, was much higher than on the other wind farms along the Zuid- and Noord-Holland coast, which were subject to the outflow of the Rhine and the northward current. Though the Borssele and Gemini sites did experience tidal currents, the net current was relatively weak. 


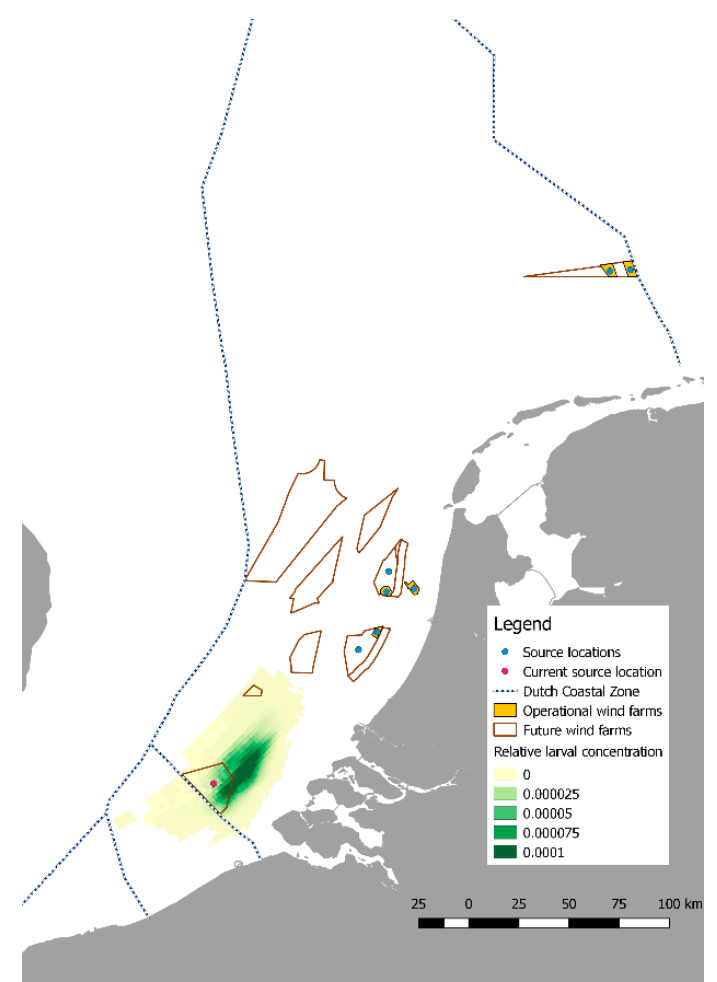

(a)

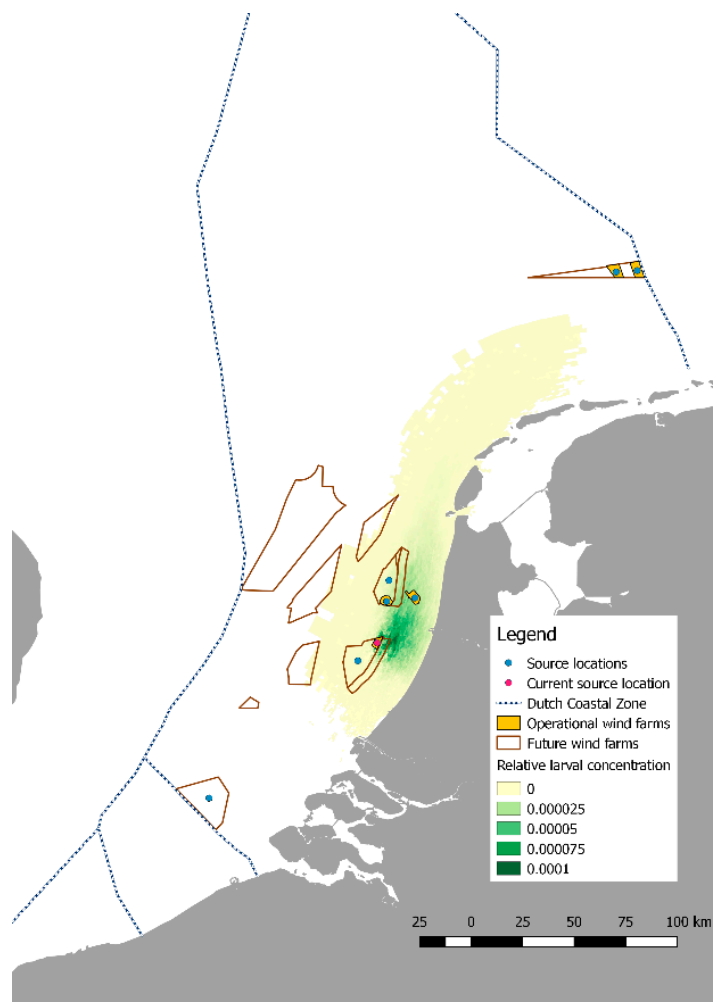

(c)

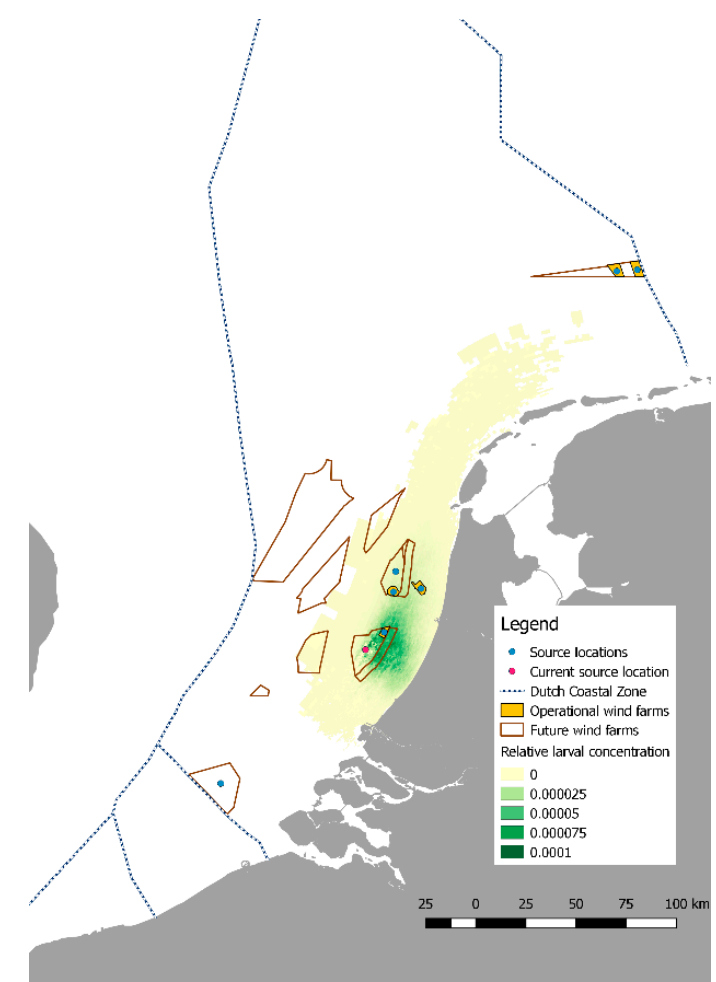

(b)

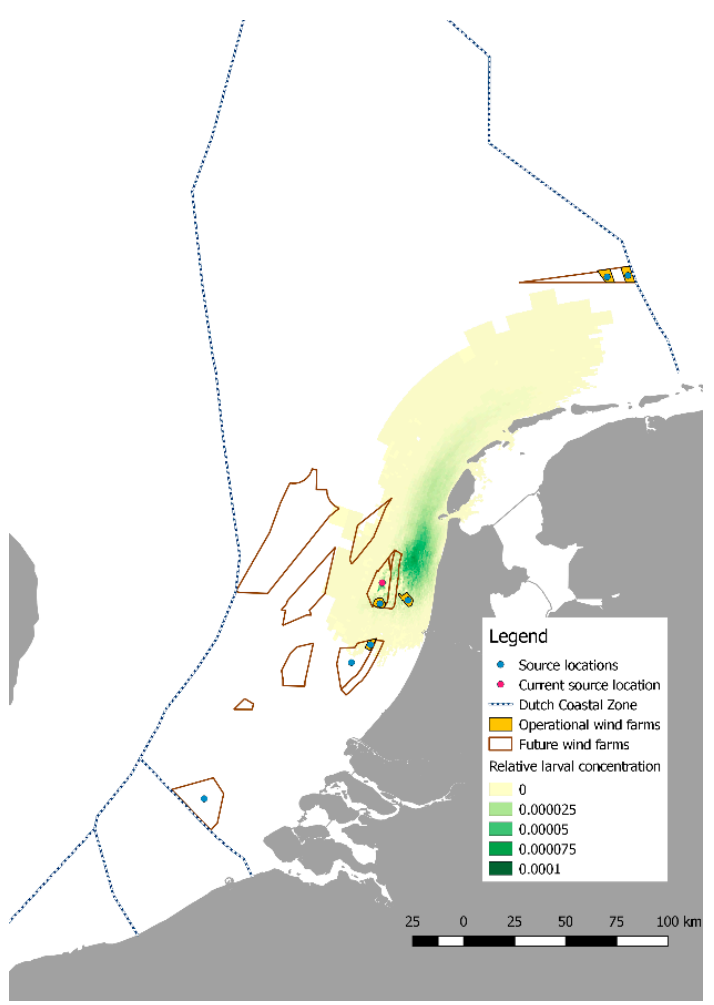

(d)

Figure 9. Cont. 


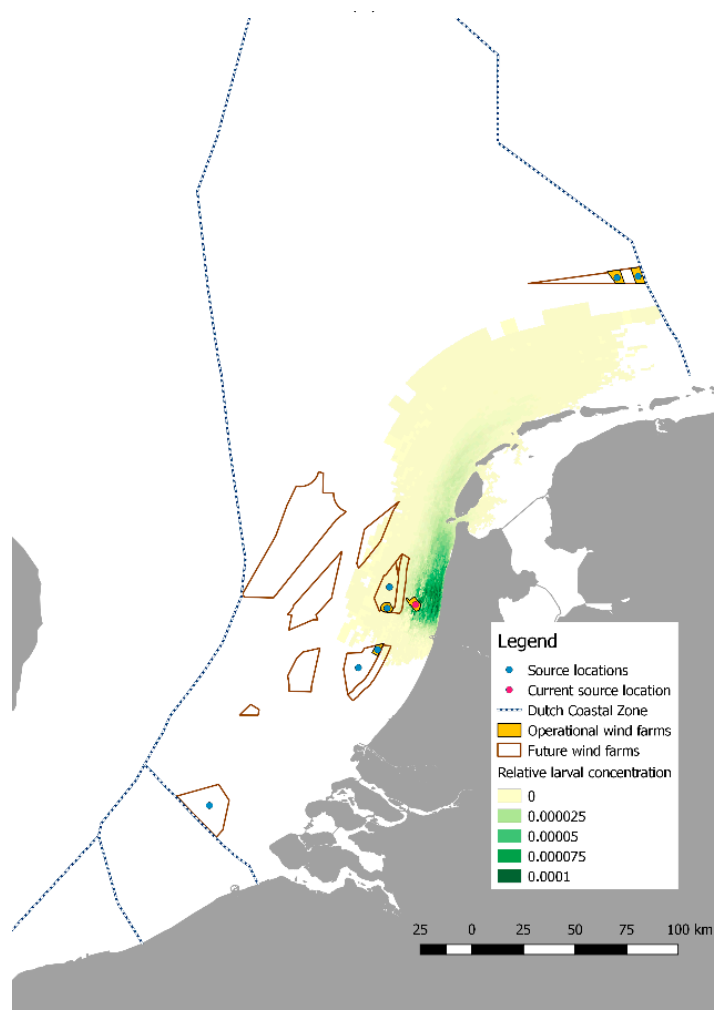

(e)

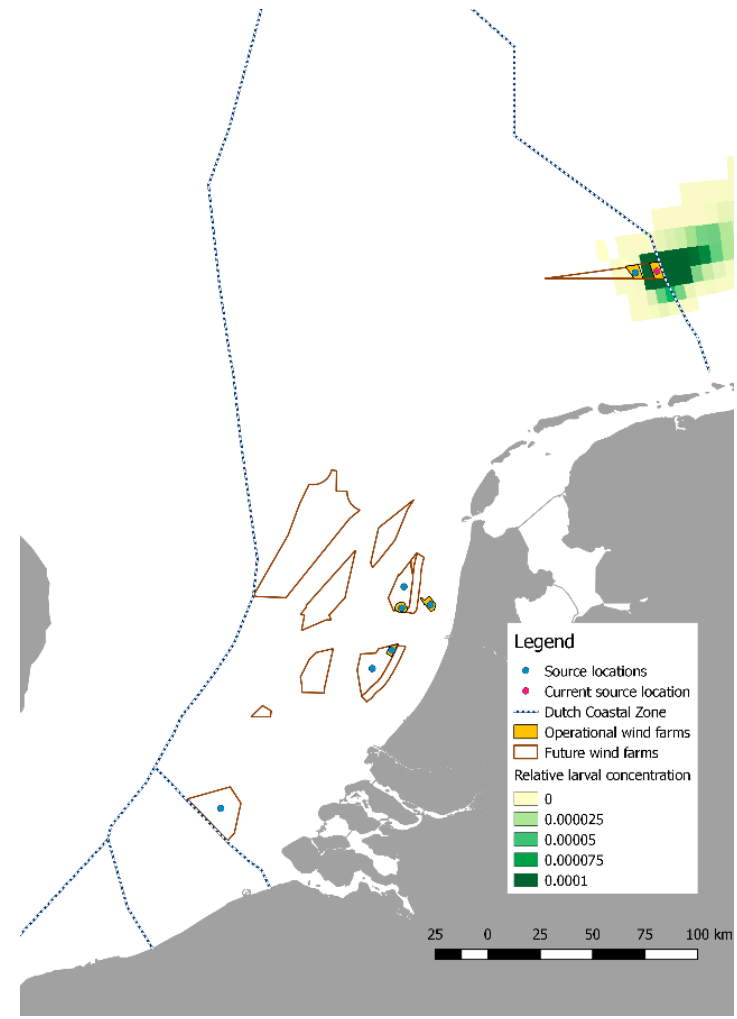

(g)

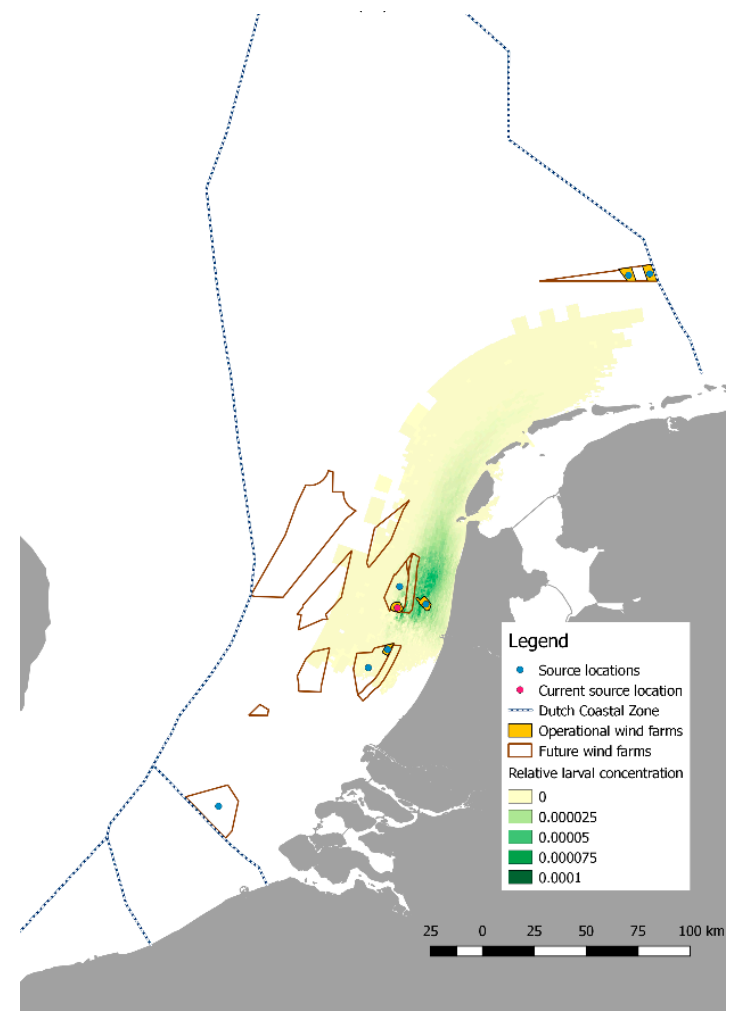

(f)

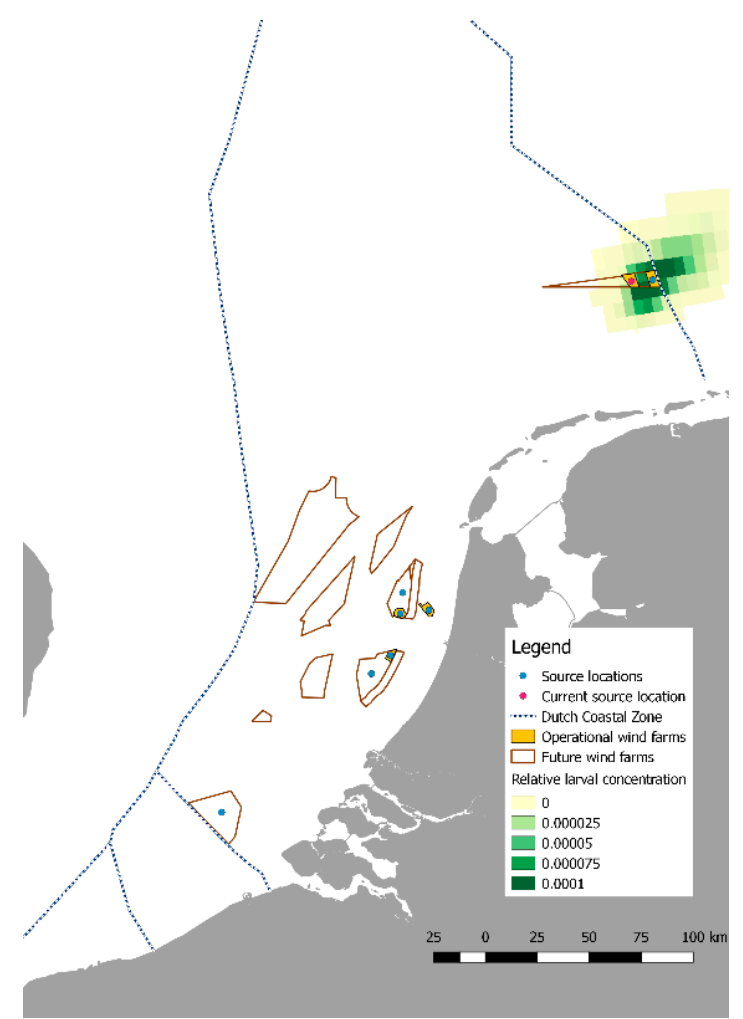

(h)

Figure 9. Simulated larval dispersal over a 10-day period at wind farms: (a) Borssele; (b) HK-Zuid; (c) Luchterduinen; (d) HK-Noord; (e) OWEZ; (f) Prinses Amalia; (g) Buitengaats; and (h) Zee-Energie. The legend presents relative concentration values. This means that the figure presents dispersal rather than absolute concentration figures. 


\subsection{Size of Parent Stock}

"Critical mass" is defined as the quantity of oysters required to ensure a larval abundance that is sufficient for potentially successful spat settlement and survival in the bed of origin. Estimates in the literature as to the required critical mass are quite diverse. According to [60], a very large oyster population in the North Sea is required-many tens of millions of individual oysters-if successful recruitment is to be achieved in the North Sea and the Wadden Sea. This is linked to the openness of these systems and the origin of the larvae, which, according to these authors, originate principally from the English Channel. However, Smyth et al. (2016) [55] have demonstrated that following a period of over-exploitation, a flat oyster population in Strangford Lough recovered on the basis of a limited critical mass of flat oysters.

\section{Results and Discussion}

\subsection{Wind Farm Selection}

The various sites experienced different levels of sea bed shear stress, with the lowest values found in the Gemini area and on the Zee-Energie and Buitengaats wind farms (Table 3). The values for the habitat characteristics were retrieved from the maps shown in Figures 5-8, and were compared to the tolerance range and optimum range for $\mathrm{O}$. edulis presented in Table 2. This resulted in a score of two (green, more suitable) when the values were within the optimal range, or one (orange, less suitable) when the values were within the tolerance range but not optimal. For the historical occurrence, 2 indicated that it was within the historical range, and 1 indicated that it was not within the historical range in that area. For larval retention, the locations scored a two when the map showed a relatively small area of larval distribution, whereas the other locations scored a one.

At most wind farms, bed shear stress corresponded with sea bed sediment composition; the seabed at Zee-Energie contained slightly larger amounts of silt. With respect to survival, the highest scores were for Zee-Energie, Buitengaats, and Borssele, which were all relatively close to sites where flat oysters occurred in the past (Table 3). The coastal sites attracted lower scores in terms of sea bed shear stress, sediment composition, and historical range. Growth and reproduction mainly depended on the availability of food, which was determined by the presence of phytoplankton and suspended particles. Though phytoplankton was not seen as a limiting factor in the potential wind farm sites analyzed in this study, suspended particles did qualify as an inhibitor. For that reason, to what extent the levels of near-seabed suspended particles differ and have limiting effects was determined among the various wind farm sites. Such an effect was found only at offshore wind farm Egmond aan Zee (OWEZ), the site which was closest to the coast (Table 3). Regarding the chance of settlement, model simulations showed that Buitengaats qualified for potentially successful recruitment, especially from a relatively small parent population at Zee-Energie, aided by proximity and the net eastward current (Table 3). The simulations also showed that the Prinses Amalia site should be able to serve as a source for spat settlement in OWEZ. With a moderate population, the Borssele wind farm could see successful recruitment within its boundaries; the same applies to Luchterduinen.

The analysis showed that Zee-Energie combined with Buitengaats were relatively suitable for the development of oyster beds; Borssele was also deemed suitable, followed by Luchterduinen. Luchterduinen also qualified as a pilot site because it was already in use and was favorably situated from a logistics point of view. The shallower coastal sites also offered opportunities for developing flat oyster beds, but the seabed in these locations was slightly less stable and they experienced more larval outflow without immediately benefiting neighboring sites. 
Table 3. Overview of relative suitability of wind farm sites for the development of flat oyster beds. Numbers indicate relative suitability, 2 is more suitable than 1 . The last column is the sum of all scores.

\begin{tabular}{cccccccc}
\hline Wind Farm & $\begin{array}{c}\text { Sea Bed } \\
\text { Shear Stress }\end{array}$ & Suspended & Matter & Sediment & $\begin{array}{c}\text { Historical } \\
\text { Occurrence }\end{array}$ & $\begin{array}{c}\text { Larval } \\
\text { Retention }\end{array}$ & Sum \\
\hline avg & max & avg & & & & \\
\hline Borssele & 1 & 2 & 2 & 1 & 2 & 2 & 10 \\
HK-Zuid & 1 & 2 & 2 & 1 & 1 & 1 & 8 \\
OWEZ & 1 & 1 & 2 & 1 & 1 & 2 & 8 \\
HK-Noord & 1 & 2 & 2 & 1 & 1 & 1 & 8 \\
Luchterduinen & 1 & 2 & 2 & 1 & 1 & 2 & 9 \\
Princes Amalia & 1 & 2 & 2 & 1 & 1 & 1 & 8 \\
Buitengaats & 2 & 2 & 2 & 1 & 2 & 1 & 10 \\
Zee-energie & 2 & 2 & 2 & 2 & 2 & 2 & 12 \\
\hline
\end{tabular}

\subsection{Pilot Studies}

Given the habitat characteristics of several wind farms in the Dutch section of the North Sea, some of those sites, in principle, provide opportunities for the development of flat oyster beds. However, information on the abundance of predators is lacking. In addition, it is unclear which critical population size is required for a self-sustaining oyster bed. To verify actual suitability of offshore wind farms for flat oyster restoration, empirical tests are needed before large-scale restoration efforts are started.

Uncertainties can be reduced by conducting pilot studies in the field to identify the most relevant factors. Experiences gained in the pilot studies provide a basis for development of pilots in wind farms in the Dutch North Sea, these include: Studies conducted by nature conservation organizations ARK and WWF at the Dutch Voordelta [110-112], at Borkum Reef, and at the wind farm Gemini in the Dutch North Sea (www.platteoester.nl); experiments carried out with flat oysters around the North Sea (RESTORE project in Germany, https:/ / www.awi.de/en/science/biosciences/shelfsea-system-ecology/main-research-focus/european-oyster.html; Solent Oyster Restoration project https://www.bluemarinefoundation.com/project/solent/); the Essex Native Oyster Restoration Initiative (ENORI) (https:/ / www.zsl.org/regions/uk-europe/thames-conservation/native-oysterrestoration), both of which were carried out in England; the DEEP project in Scotland (http:/ / www.theglenmorangiecompany.com/about-us/deep/); and the Bivalve Project in Sweden.

The objective of such a pilot study could be formulated as follows: Conducting practical tests of life history variables to establish (1) the extent to which flat oysters are able to survive, grow, and reproduce on the chosen site; (2) whether the oyster bed is able to sustain itself through recruitment (larval production and sufficient substrate for settlement); (3) the extent to which the oyster bed can serve as a habitat for other species; and (4) which features within wind farms are most suitable to use for restoration efforts.

In outline, the following approach could be pursued: (1) Create a source of larvae; and (2) provide suitable substrate. To generate a source of larvae it is necessary to establish a minimum flat oyster population with different age (= size) classes, of which a part is protected against predators. Oyster development will have to be monitored during the growth and spawning seasons for survival, growth, and gonad development. An effective way to study survival, growth, and reproduction is to install cages with oysters for monitoring. During the spawning season, water samples can be taken to establish the larval abundance. Spat collectors can be used to monitor larval settlement. Clean shell materials (e.g., mussels and oysters) can be deposited at the pilot site during the period of peak larval abundance to serve as substrate to promote the settlement of flat oyster larvae.

Additionally, morphodynamic developments need to be monitored. The scour protection around turbines provides an area with hard substrate that may be suitable (or can be made suitable) for oyster settlement. However, these constructions can often induce edge scour along the edges [113]. These scour holes can be very dynamic and may prevent the expansion of an oyster bed. Whether this is a limiting issue or not will depend on the local dynamics within wind farm locations. Another option in 
a wind farm may be to utilize the protective layers over cable crossings. However, there remains a major discussion on the requirements to decommission any anthropogenic structures in the North Sea (OSPAR), which conflicts with the concept of long-term nature development strategies.

A combination of oyster culture and oyster restoration is an option. Off-bottom oyster growth in the open sea has been demonstrated to be possible [114]. The oysters will spawn at least once before they reach market size and are harvested. The larvae that are produced may be able to settle on substrate placed on the bottom. This will enlarge the population of the natural bed. When the bed has become larger than is needed to sustain itself, controlled harvest from the bottom can be investigated. Oyster farmers may be interested in explorative experiments. Apart from off-bottom farming systems, an area set aside for such activities and more robust ships are needed. At present, farmers are reluctant to invest in equipment and new ships without guarantees for the long-term (e.g., 10 years) use of an area. Possibilities for the government to allow such long-term experiments, and combined use of wind farm service vessels, need to be explored.

\section{Conclusions}

Our analysis showed that a number of wind farms in the Dutch section of the North Sea are suitable locations for flat oysters and for the development of flat oyster beds. This offers opportunities for multi-use in the form of nature-inclusive construction and exploitation. It can support the achievement of biodiversity goals, the restoration of ecosystem functions, and the enhancement of ecosystem services, including future seafood production. To verify actual suitability of off shore wind farms for flat oyster restoration, empirical tests are needed before large-scale restoration efforts can be started. Pilots should focus on estimation of life history variables of the oysters, including survival, growth, reproduction, and recruitment. In addition, expansion of the bed and self-sustainability, by the positive feedback created from the provision of new settlement substrate by the newly established bed, should be studied, as well as the enhancement of biodiversity in general and the increased production of fish and large, mobile crustaceans in particular. Combining oyster restoration with oyster culture for commercial purposes is a viable option worth investigating. It could be very productive, as cultivation offers broodstock for larvae, which can expand and maintain the natural bed, and harvest adds to food security.

Author Contributions: P.K. lead the writing of the manuscript and provided, together with T.M.v.d.H and A.C.S., biological information on O.edulis and its habitat. L.A.v.D. provided information and wrote on physical habitat conditions and larval dispersal. F.K. provided larval dispersal model results. B.W. provided information and wrote on goods and services of oyster beds. M.P. provided information and wrote on oyster aquaculture and M.K. provided information and wrote on food security. The authors declare no conflict of interest.

Funding: Part of this study was funded by the Dutch Ministry of Economic Affairs, project code: BO-11018. Writing of the manuscript was supported by the Wageningen Research project KB22.

Conflicts of Interest: The authors declare no conflict of interest.

\section{References}

1. Béné, C.; Barange, M.; Subasinghe, R.; Pinstrup-Andersen, P.; Merino, G.; Hemre, G.; Williams, M. Feeding 9 billion by 2050 Putting fish back on the menu. Food Secur. 2015, 7, 261-274. [CrossRef]

2. Lovatelli, A.; Aguilar-Manjarrez, J.; Soto, D. (Eds.) Expanding Mariculture Farther Offshore-Technical, Environmental, Spatial and Governance Challenges; FAO Technical Workshop, FAO Fisheries and Aquaculture Proceedings No. 24; Food and Agriculture Organization of the United Nations (FAO): Rome, Italy, 2013; p. 73.

3. Rubino, M.C. Offshore Aquaculture in the United States: Economic Considerations, Implications and Opportunities; Technical Memorandum NMFS F/SPO-103; National Oceanic and Atmospheric Administration: Silver Spring, MD, USA, 2008. 
4. Godfray, H.C.J.; Beddington, J.R.; Crute, I.R.; Haddad, L.; Lawrence, D.; Muir, J.F.; Pretty, J.; Robinson, S.; Thomas, S.M.; Toulmin, C. Food Security: The Challenge of Feeding 9 Billion People. Science 2010, 327, 812-818. [CrossRef] [PubMed]

5. Costello, C.; Ovando, D.; Clavelle, T.; Strauss, C.K.; Hilborn, R.; Melnychuk, M.C.; Branch, T.A.; Gaines, S.D.; Szuwalski, C.S.; Cabral, R.B.; et al. Global fishery prospects under contrasting management regimes. PNAS 2016, 113, 5125-5129. [CrossRef] [PubMed]

6. Goldberg, R.; Naylor, R. Future seascapes, fishing and fish farming. Front. Ecol. Environ. 2005, 3, $21-28$. [CrossRef]

7. Borja, Á.; Rodríguez, J.G.; Black, K.; Bodoy, A.; Emblow, C.; Fernandes, T.F.; Forte, J.; Karakassis, I.; Muxika, I.; Nickell, T.D.; et al. Assessing the suitability of a range of benthic indices in the evaluation of environmental impact of fin and shellfish aquaculture located in sites across Europe. Aquaculture 2009, 293, 231-240. [CrossRef]

8. Read, P.; Fernandes, T. Management of environmental impacts of marine aquaculture in Europe. Aquaculture 2003, 226, 139-163. [CrossRef]

9. Lester, S.E.; Stevens, J.M.; Gentry, R.R.; Kappel, C.V.; Bell, T.W.; Costello, C.J.; Gaines, S.D.; Kiefer, D.A.; Maue, C.C.; Rensel, J.E.; et al. Marine spatial planning makes room for offshore aquaculture in crowded coastal waters. Nat. Commun. 2018, 9, 945. [CrossRef] [PubMed]

10. Sarà, G.; Mangano, M.C.; Johnson, M.; Mazzola, A. Integrating multiple stressors in aquaculture to build the blue growth in a changing sea. Hydrobiologia 2018, 809, 5-17. [CrossRef]

11. Van den Burg, S.W.K.; Kamermans, P.; Blanch, M.; Pletsas, D.; Poelman, M.; Soma, K.; Dalton, G. Business case for mussel aquaculture in offshore wind farms in the North Sea. Mar. Policy 2017. [CrossRef]

12. Jansen, H.M.; van den Burg, S.; Bolman, B.; Jak, R.G.; Kamermans, P.; Poelman, M.; Stuiver, M. The feasibility of offshore aquaculture and its potential for multi-use in the North Sea. Aquacult. Int. 2016. [CrossRef]

13. Gentry, R.R.; Froehlich, H.E.; Grimm, D.; Kareiva, P.; Parke, M.; Rust, M.; Gaines, S.D.; Halpern, B.S. Mapping the global potential for marine aquaculture. Nat. Ecol. Evol. 2017, 1, 1317-1324. [CrossRef] [PubMed]

14. Pirlet, H.; Claus, S.; Copejans, E.D.C.E.; Guanche García, R.; Møhlenberg, F.; Rappé, K.; Schouten, J.-J.; Zanuttigh, B. The Mermaid Project-Innovative Multi-Purpose Offshore Platforms; Flanders Marine Institute (VLIZ): Ostend, Belgium, 2014; p. 20.

15. Quevedo, E.; Delory, E.; Castro, A.; Llinás, O.; Hernández, J. Modular multi-purpose offshore platforms, the TROPOS project approach. In Proceedings of the 4th International Conference on Ocean Energy, Dublin, Ireland, 17-19 October 2012.

16. Olsen, O.T. The Piscatorial Atlas of the North Sea, English and St. George's Channels; Grimsby: London, UK, 1883.

17. Gercken, J.; Schmidt, A. Current Status of the European Oyster (Ostrea edulis) and Possibilities for Restoration in the German North Sea 2014; BFN Report; Bundesamt für Naturschutz: Bonn, Germany, 2014.

18. Houziaux, J.-S.; Kerckhof, F.; Degrendele, K.; Roche, M.; Norro, A. The Hinder Banks Yet an Important Region for the Belgian Marine Biodiversity? Final Report HINDERS Project; Belgian Science Policy Office: Brussels, Belgium, 2008; p. 249. Available online: http://www.belspo.be/belspo/home/publ/pub_ostc/ EV/rappEV45_en.pdfS (accessed on 28 August 2018).

19. Bruno, J.F.; Stachowicz, J.J.; Bertness, M.D. Inclusion of facilitation into ecological theory. Trends Ecol. Evol. 2003, 18, 119-125. [CrossRef]

20. Bouma, T.J.; Olenin, S.; Reise, K.; Ysebaert, T. Ecosystem engineering and biodiversity in coastal sediments: Posing hypotheses. Helgol. Mar. Res. 2009, 63, 95-106. [CrossRef]

21. Lenihan, H.S.; Peterson, C.H. How habitat degradation through fishery disturbance enhances impacts of hypoxia on oyster reefs. Ecol. Appl. 1998, 8, 128-140. [CrossRef]

22. zu Ermgassen, P.S.E.; Grabowski, J.H.; Gair, J.R.; Powers, S.P. Quantifying fish and mobile invertebrate production from a threatened nursery habitat. J. Appl. Ecol. 2016, 53, 596-606. [CrossRef]

23. Baggett, L.P.; Powers, S.P.; Brumbaugh, R.; Coen, L.D.; DeAngelis, B.; Greene, J.; Hancock, B.; Morlock, S. Oyster Habitat Restoration Monitoring and Assessment Handbook; The Nature Conservancy: Arlington, VA, USA, 2014; 96p, Available online: http:/ / www.oyster-restoration.org/wp-content/uploads/2014/01/OysterHabitat-Restoration-Monitoring-and-Assessment-Handbook.pdf (accessed on 28 August 2018).

24. Zwerschke, N.; Emmerson, M.C.; Roberts, D.; O'Connor, N.E. Benthic assemblages associated with native and non-native oysters are similar. Mar. Pollut. Bull. 2016, 111, 305-310. [CrossRef] [PubMed] 
25. Smyth, D.; Roberts, D. The European oyster (Ostrea edulis) and its epibiotic succession. Hydrobiologia 2010, 655, 25-36. [CrossRef]

26. Newell, R.I.E. Ecosystem influences of natural and cultivated populations of suspension-feeding bivalve molluscs: A review. J. Shellfish Res. 2004, 23, 51-61.

27. Kellogg, M.L.; Cornwell, J.C.; Owens, M.S.; Paynter, K.T. Denitrification and nutrient assimilation on a restored oyster reef. Mar. Ecol. Prog. Ser. 2013, 480, 1-19. [CrossRef]

28. Dame, R.F.; Prins, T. Bivalve carrying capacity in coastal ecosystems. Aquat. Ecol. 1997, 31, 409-421. [CrossRef]

29. Van der Zee, E.; Heide, T.; Donadi, S.; Eklöf, J.; Eriksson, B.; Olff, H.; Veer, H.; Piersma, T. Spatially extended habitat modification by intertidal reef-building bivalves has implications for consumer-resource interactions. Ecosystems 2012, 15, 664-673. [CrossRef]

30. Van Oevelen, D.; Duineveld, G.; Lavaleye, M.; Mienis, F.; Soetaert, K.; Heip, C.H.R. The cold-water coral community as a hot spot for carbon cycling on continental margins: A food-web analysis from Rockall Bank (northeast Atlantic). Limnol. Oceanogr. 2009, 54, 1829-1844. [CrossRef]

31. De Smet, B.; van Oevelen, D.; Vincx, M.; Vanaverbeke, J.; Soetaert, K. Lanice conchilega structures carbon flows in soft-bottom intertidal areas. Mar. Ecol. Prog. Ser. 2016, 552, 47-60. [CrossRef]

32. Van der Heide, T.; Tielens, E.; van der Zee, E.M.; Weerman, E.J.; Holthuijsen, S.; Eriksson, B.K.; Piersma, T.; van de Koppel, J.; Olff, H. Predation and habitat modification synergistically interact to control bivalve recruitment on intertidal mudflats. Boil. Conserv. 2014, 172, 163-169. [CrossRef]

33. Ysebaert, T.; Hart, M.; Herman, P.M.J. Impacts of bottom and suspended cultures of mussels Mytilus spp. on the surrounding sedimentary environment and macrobenthic biodiversity. Helgol. Mar. Res. 2009, 63, 59-74. [CrossRef]

34. Puls, W.; Sündermann, J. Simulation of Suspended Sediment Dispersion in the North Sea. In Residual Currents and Long-Term Transport; Coastal and Estuarine Studies; Springer: Berlin, Germany, 1990; Volume 38.

35. Korringa, P. The shells of Ostrea edulis as a habitat. Arch. Neerl. Zoöl. 1954, 10, 32-146. [CrossRef]

36. Reise, K.; Beusekom, J.E.E. Interactive effects of global and regional change on a coastal ecosystem. Helgol. Mar. Res. 2008, 62, 85-91. [CrossRef]

37. Ministry of Economic Affairs. 2014 Nature Ambition Large Water Bodies. Available online: www.minez.nl (accessed on 28 August 2018).

38. Ministry of Economic Affairs. 2013 Implementation Agenda Natural Capital. Available online: www.minez. $\mathrm{nl}$ (accessed on 28 August 2018).

39. High Level Panel of Experts. Sustainable Fisheries and Aquaculture for Food Security and Nutrition: A Report by the High Level Panel of Experts on Food Security and Nutrition of the Committee on World Food Security; FAO: Rome, Italy, 2014.

40. Golden, C.D.; Allison, E.H.; Cheung, W.W.L.; Dey, M.M.; Halpern, B.S.; McCauley, D.J. Nutrition: Fall in fish catch threatens human health. Nature 2016, 534, 317-320. [CrossRef] [PubMed]

41. Allison, E.H.; Béné, C.; Andrew, N.L. Poverty reduction as a means to enhance resilience in small-scale fisheries. In Small-Scale Fisheries Management_Frameworks and Approaches for the Developing World; Pomeroy, R.S., Andrew, N.L., Eds.; CABI: Wallingford, UK, 2011; pp. 216-238.

42. Béné, C.; Arthur, R.; Norbury, H.; Allison, E.H.; Beveridge, M.; Bush, S.; Campling, L.; Leschen, W.; Little, D.; Squires, D.; et al. Contribution of fisheries and aquaculture to food security and poverty reduction: Assessing the current evidence. World Dev. 2016, 79, 177-196. [CrossRef]

43. Beveridge, M.C.M.; Thilsted, S.H.; Phillips, M.J.; Metian, M.; Troell, M.; Hall, S.J. Meeting the food and nutrition needs of the poor: The role of fish and the opportunities and challenges emerging from the rise of aquaculture. J. Fish Boil. 2013, 83, 1067-1084. [CrossRef] [PubMed]

44. Kolding, J.; van Zwieten, P.; Marttin, F.; Poulain, F. Fisheries in the Drylands of Sub-Sahara. Fish Come with the Rains; Building Resilience for Fisheries Dependant Livelihoods to Enhance Food Security and Nutrition in the Drylands; FAO Report FIAF/FIAP/C1118(En).7; Food and Agriculture Organization of the United Nations (FAO): Rome, Italy, 2016.

45. Bogard, J.R.; Thilsted, S.H.; Marks, G.C.; Abdul Wahab, M.; Hossain, M.A.R.; Jakobsen, J.; Stangoulis, J. Nutrient composition of important fish species in Bangladesh and potential contribution to recommended nutrient intakes. J. Food Compos. Anal. 2015, 42, 120-133. [CrossRef] 
46. Kurien, J. Responsible Fish Trade and Food Security; FAO Fisheries Technical Paper 456; Food and Agriculture Organization of the United Nations (FAO): Rome, Italy, 2005.

47. Pelletier, N.; Audsley, E.; Brodt, S.; Garnett, T.; Henriksson, P.; Kendall, A.; Kramer, K.J.; Murphy, D.; Nemecek, T.; Troell, M. Energy Intensity of Agriculture and Food Systems. Annu. Rev. Environ. Resour. 2011, 36, 223-246. [CrossRef]

48. Hilborn, R.; Tellier, P. The Environmental Cost of N. Z. Food Production; New Zealand Seafood Industry Council Ltd.: Wellington, New Zealand, 2012; ISBN 978-0473-17824-6.

49. Hall, S.J.; Delaporte, A.; Phillips, M.J.; Beveridge, M.; O'Keefe, M. Blue Frontiers: Managing the Environmental Costs of Aquaculture; The WorldFish Center: Penang, Malaysia, 2011.

50. Garcia, S.M.; Kolding, J.; Rice, J.; Rochet, M.J.; Zhou, S.; Arimoto, T.; Beyer, J.E.; Borges, L.; Bundy, A.; Dunn, D. Reconsidering the consequences of selective fisheries. Science 2012, 335, 1045-1047. [CrossRef] [PubMed]

51. Smaal, A.C.; Kamermans, P.; van der Have, T.M.; Engelsma, M.; Sas, H.W.J. Feasibility of Flat Oyster (Ostrea edulis) Restoration in the Dutch Part of the North Sea; IMARES Report C028/15; IMARES Wageningen UR: Ijmuiden, The Netherlands, 2015.

52. Smaal, A.; Kamermans, P.; Kleissen, F.; van Duren, L.; van der Have, T. Flat Oysters on Offshore Wind Farms. Opportunities for the Development of flat Oyster Populations on Existing and Planned Wind Farms in the Dutch Section of the North Sea; Wageningen Marine Research Rapport C052/17; Wageningen Marine Research: Yerseke, The Netherlands, 2017.

53. Kerckhof, F.; Coolen, J.W.P.; Rumes, B.; Degraer, S. Recent findings of wild European flat oysters Ostrea edulis (Linnaeus, 1758) in Belgian and Dutch offshore waters: New perspectives for offshore oyster reef restoration in the southern North Sea Belgian. J. Zoöl. 2018. [CrossRef]

54. Burke, K.; Bataller, É.; Miron, G. Spat collection of a non-native bivalve species (European oyster, Ostrea edulis) off the Eastern Canadian coast. J. Shellfish Res. 2008, 27, 345-353. [CrossRef]

55. Smyth, D.; Mahon, A.M.; Roberts, D.; Kregting, L. Settlement of Ostrea edulis is determined by the availability of hard substrata rather than by its nature: Implications for stock recovery and restoration of the European oyster. Aquat. Conserv. Mar. Freshw. Ecosyst. 2018. [CrossRef]

56. Walne, P.R. Culture of Bivalve moLluscs: 50 Years of Experience at Conwy; Fishing News Books Ltd.: Farnham, UK, 1974; 189p.

57. O'Foighil, D. Role of spermatozeugmata in the spawning ecology of the brooding oyster Ostrea edulis. Gamete Res. 1989, 24, 219-228. [CrossRef] [PubMed]

58. Muus, B.J.; Dahlstrom, P. Meeresfische; BLV: Munchen, Germany, 1973.

59. Jackson, A. Ostrea edulis. Native oyster. Marine Life Information Network: Biology and Sensitivity Key Information Sub-Programmem [on-line]; Marine Biological Association: Plymouth, UK, 2007.

60. Berghahn, R.; Ruth, M. The disappearance of oysters from the Wadden Sea: A cautionary tale for no-take zones. Aquat. Conserv. Mar. Freshw. Ecosyst. 2005, 15, 91-104. [CrossRef]

61. Jordan-Cooley, W.C.; Lipcius, R.N.; Shaw, L.B.; Shen, J.; Shi, J. Bistability in a differential equation model of oyster population and sediment volume. J. Theor. Boil. 2011, 289, 1-11. [CrossRef] [PubMed]

62. Kennedy, R.J.; Roberts, D. Commercial oyster stocks as a potential source of larvae in the regeneration of Ostrea edulis in Strangford Lough, Northern Ireland. JMBA 2006, 86, 153-159. [CrossRef]

63. Vera, M.; Carlsson, J.; Carlsson, J.E.L.; Cross, T.; Lynch, S.; Kamermans, P.; Villalba, A.; Culloty, S.; Martinez, P. Current genetic status, temporal stability and structure of the remnant wild European flat oyster populations: Conservation and restoring implications. Mar. Biol. 2016, 163, 239. [CrossRef]

64. Smyth, D.; Kregting, L.; Elsäßer, B.; Kennedy, R.; Roberts, D. Using particle dispersal models to assist in the conservation and recovery of the overexploited native oyster (Ostrea edulis) in an enclosed sea lough. JSR 2016, 108, 50-59. [CrossRef]

65. Capelle, J.J. Restoration of the Oyster Ostrea edulis L. in the Wadden Sea; Wageningen IMARES, Rapport; IMARES: Yerseke, The Netherlands, 2008; p. 61.

66. Haure, J.; Penisson, C.; Bougrier, S.; Baud, J.P. Influence of temperature on clearance and oxygen consumption rates of the flat oyster Ostrea edulis: Determination of allometric coefficients. Aquaculture 1998, 169, $211-224$. [CrossRef] 
67. Newell, R.C.; Johnson, L.G.; Kofoed, L.H. Adjustment of the components of energy balance in response to temperature change in Ostrea edulis. Oecologia 1977, 30, 97-110. [CrossRef] [PubMed]

68. Lubet, P. Ecophysiologie de la reproduction chez les mollusques lamellibranches. Haliotis 1976, 7, 49-55.

69. Buxton, C.D.; Newell, R.C.; Field, J.G. Response-Surface Analysis of the Combined Effects of Exposure and Acclimation Temperatures on Filtration, Oxygen Consumption and Scope for Growth in the Oyster. Mar. Ecol. Prog. Ser. 1981, 6, 73-82. [CrossRef]

70. Davis, H.C.; Calabrese, A. Survival and growth of larvae of the European oyster (Ostrea edulis L.) at different temperatures. Boil. Bull. 1969, 136, 193-199. [CrossRef] [PubMed]

71. Hoek, P.P.C. Rapport Over de Oorzaken van den Achteruitgang in Hoedanigheid van de Zeeuwsche oester; Ministerie van Waterstaat, Handel en Nijverheid: 's-Gravenhage, The Netherlans, 1902.

72. Child, A.R.; Laing, I. Comparative low temperature tolerance of small juvenile European, Ostrea edulis L.; Pacific oysters, Crassostrea gigas Thunberg. Aquac. Res. 1998, 29, 103-113. [CrossRef]

73. Davis, H.C.; Ansell, A.D. Survival and growth of larvae of the European oyster (Ostrea edulis L.) at lowered salinities. Boil. Bull. 1962, 122, 33-39. [CrossRef]

74. Hutchinson, S.; Hawkins, L.E. Quantification of the physiological responses of the European flat oyster, Ostrea edulis L. to temperature and salinity. J. Molluscan Stud. 1992, 58, 215-226. [CrossRef]

75. Hayward, P.J.; Ryland, J.S. Handbook of the Marine Fauna of North-West Europe; Oxford University Press: New York, NY, USA, 1998.

76. Drinkwaard, A.C. Current velocity as an ecological factor in shell growth of Ostrea edulis. ICES Shellfish Committee 1961, 47, 1-3.

77. Grant, J.; Enright, C.T.; Griswold, A. Resuspension and growth of Ostrea edulis: A field experiment. Mar. Boil. 1990, 104, 51-59. [CrossRef]

78. Tillin, H.M.; Hull, S.C. Tools for Appropriate Assessment of Fishing and Aquaculture Activities in Marine and Coastal Natura 2000 Sites; Report VII: Intertidal and Subtidal Reefs, Report No. R. 2074; ABPmer for the Marine Institute: Galway, Ireland, 2013.

79. Hawkins, A.J.S.; Bayne, B.L.; Bougrier, S.; Héral, M.; Iglesias, J.I.P.; Navarro, E.; Smith, R.F.M.; Urrutia, M.B. Some general relationships in comparing the feeding physiology of suspensionfeeding bivalve molluscs. J. Exp. Mar. Boil. Ecol. 1998, 219, 87-103. [CrossRef]

80. Barillé, L.; Prou, J.; Heral, M.; Razet, D. Effects of high natural seston concentrations on the feeding, selection, and absorption of the oyster Crassostrea gigas Thunberg. JEMBE 1997, 2012, 149-172. [CrossRef]

81. Millican, P.F.; Helm, M.M. Effects of nutrition on larvae production in the European flat Oyster, Ostrea edulis. Aquaculture 1994, 123, 83-94. [CrossRef]

82. Davis, J.C. Minimal Dissolved Oxygen Requirements of Aquatic Life with Emphasis on Canadian Species: A Review. J. Fish. Board Can. 1975, 32, 2295-2332. [CrossRef]

83. Borsje, B.W.; Bouma, T.J.; Rabaut, M.; Herman, P.M.J.; Hulscher, S.J.M.H. Formation and erosion of biogeomorphological structures: A model study on the tube-building polychaete Lanice conchilega. Limnol. Oceanogr. 2014, 59, 1297-1309. [CrossRef]

84. Buijsman, M.C.; Ridderinkhof, H. Long-term evolution of sand waves in the Marsdiep inlet. II: Relation to hydrodynamics. Cont. Shelf Res. 2008, 28, 1202-1215. [CrossRef]

85. Dorst, L.L.; Roos, P.C.; Hulscher, S.J.M.H.; Lindenbergh, R.C. The estimation of sea floor dynamics from bathymetric surveys of a sand wave area. J. Appl. Geodesy 2009, 3, 97-120. [CrossRef]

86. Abelson, A.; Weihs, D.; Loya, Y. Hydrodynamic impediments to settlement of marine propagules, and adhesive-filament solutions. Limnol. Oceanogr. 1994, 39, 164-169. [CrossRef]

87. Crimaldi, J.P.; Thompson, J.K.; Rosman, J.H.; Lowe, R.J.; Koseff, J.R. Hydrodynamics of larval settlement: The influence of turbulent stress events at potential recruitment sites. Limnol. Oceanogr. 2002, 47, 1137-1151. [CrossRef]

88. Hendriks, I.E.; van Duren, L.A.; Herman, P.M.J. Turbulence levels in a flume compared to the field. J. Sea Res. 2006, 55, 15-29. [CrossRef]

89. Grabowski, R.C.; Droppo, I.G.; Wharton, G. Erodibility of cohesive sediment: The importance of sediment properties. Earth-Sci. Rev. 2011, 105, 101-120. [CrossRef]

90. Wright, L.D.; Schaffner, L.C.; Maa, J.P.-Y. Biological mediation of bottom boundary layer processes and sediment suspension in the lower Chesapeake Bay. Mar. Geol. 1997, 141, 27-50. [CrossRef] 
91. McCave, I.N. Sand waves in the North Sea off the coast of Holland. Mar. Geol. 1971, 10, 199-225. [CrossRef]

92. Van Dijk, T.A.G.P.; Kleinhans, M.G. Processes controlling the dynamics of compound sand waves in the North Sea, Netherlands. J. Geophys. Res. Earth Surf. 2005, 110. [CrossRef]

93. Damen, J.M.; van Dijk, T.A.G.P.; Hulscher, S.J.M.H. Spatially Varying Environmental Properties Controlling Observed Sand Wave Morphology. J. Geophys. Res. 2018, 123, 19. [CrossRef]

94. ICONA. Noordzeeatlas Voor Het Nederlandse Beleid en Beheer; ICONA Den Haag; Stadsuitgeverij: Amsterdam, The Netherlands, 1992.

95. Gerritsen, H.; Vos, R.J.; Van Der Kaaij, T.; Lane, A.; Boon, J.G. Suspended sediment modelling in a shelf sea (North Sea). Coast. Eng. 2000, 41, 317-352. [CrossRef]

96. Van der Kaaij, T.; van Kessel, T.; Troost, T.; van Duren, L.A.; Villars, M.T. Modelondersteuning MER Winning Suppletie- en Ophoogzand Noordzee 2018-2027; Modelvalidatie 1230888-002; Deltares: Delft, The Netherlands, 2017.

97. Laing, I.; Walker, P.; Areal, F. A Feasibility Study of Native Oyster (Ostrea edulis) Stock Regeneration in the United Kingdom; CARD Project Report FC1016; Centre for Environment, Fisheries \& Aquaculture Science: Lowestoft, UK, 2005.

98. Sawusdee, A.; Jensen, A.C.; Collins, K.J.; Hauton, C. Improvements in the physiological performance of European flat oysters Ostrea edulis (Linnaeus, 1758) cultured on elevated reef structures: Implications for oyster restoration. Aquaculture 2015, 444, 41-48. [CrossRef]

99. Snelgrove, P.V.R.; Butman, C.A. Animal-sediment relationships revisited: Cause versus effect. Oceanogr. Mar. Boil. Annu. Rev. 1994, 32, 111-177.

100. Houziaux, J.-S.; Fettweis, M.; Francken, F.; van Lancker, V. Historic (1900) seafloor composition in the Belgian-Dutch part of the North Sea: A reconstruction based on calibrated visual sediment descriptions. Cont. Shelf Res. 2011, 31, 1043-1056. [CrossRef]

101. Wasson, K. Informing Olympia Oyster Restoration: Evaluation of Factors That Limit Populations in a California Estuary. Wetlands 2010, 30, 449-459. [CrossRef]

102. Peirano, A. Wrecks on the Bottom: Useful, Ecological Sentinels? Mar. Technol. Soc. J. 2013, 47, $118-127$. [CrossRef]

103. Petersen, J.K.; Maar, M.; Ysebaert, T.; Herman, P.M.J. Near-bed gradients in particles and nutrients above a mussel bed in the Limfjorden: Influence of physical mixing and mussel filtration. Mar. Ecol. Prog. Ser. 2013, 490, 137-146. [CrossRef]

104. Wiles, P.J.; van Duren, L.A.; Haese, C.; Larsen, J.; Simpson, J.H. Stratification and mixing in Limfjorden in relation to mussel culture. J. Mar. Syst. 2006, 60, 129-134. [CrossRef]

105. Van Leeuwen, S.; Tett, P.; Mills, D.; van der Molen, J. Stratified and nonstratified areas in the North Sea: Long-term variability and biological and policy implications. J. Geophys. Res. 2015, 120, 4670-4686. [CrossRef]

106. Greenwood, N.; Parker, E.R.; Fernand, L.; Sivyer, D.B.; Weston, K.; Painting, S.J.; Kröger, S.; Forster, R.M.; Lees, H.E.; Mills, D.K.; et al. Detection of low bottom water oxygen concentrations in the North Sea; implications for monitoring and assessment of ecosystem health. Biogeosciences 2010, 7, 1357-1373. [CrossRef]

107. Queste, B.Y.; Fernand, L.; Jickells, T.D.; Heywood, K.J.; Hind, A.J. Drivers of summer oxygen depletion in the central North Sea. Biogeosciences 2016, 13, 1209-1222. [CrossRef]

108. Cronin, K.; Plieger, R.; Gaytan Aguilar, S.; de Lima Rego, J.R.; Blaas, M. MoS2-II: Deterministic Model Calibration: Updates of the ZUNO-DD Hydrodynamic and SPM Model Deltares Report; Rep. No. 1204561; Deltares: Delft, The Netherlands, 2013.

109. Korringa, P. Relations between the Moon and Periodicity in the Breeding of Marine Animals. Ecol. Monogr. 1947, 17, 347-381. [CrossRef]

110. Sas, H.; Kamermans, P.; van der Have, T.; Lengkeek, W.; Smaal, A. Shellfish Reef Restoration Pilots, Voordelta, The Netherlands; Annual Report; ARK Natuurontwikkeling: Nijmegen, The Netherlands, 2016.

111. Sas, H.; Kamermans, P.; van der Have, T.; Christianen, M. Shellfish reef Restoration Pilots, Voordelta, The Netherlands; Annual Report; ARK Natuurontwikkeling: Nijmegen, The Netherlands, 2017.

112. Christianen, M.J.A.; Bergsma, J.H.; Coolen, J.W.P.; Didderen, K.; Dorenbosch, M.; Driessen, F.M.F.; Kamermans, P.; Reuchlin-Hugenholtz, E.; Sas, H.; Smaal, A.; et al. Return of the native facilitated by the invasive? Population composition, substrate preferences and epibenthic species richness of a recently discovered shellfish reef with native European flat oysters (Ostrea edulis) in the North Sea. Mar. Boil. Res. 2018, 14, 590-597. [CrossRef] 
113. Petersen, T.U.; Mutlu Sumer, B.; Fredsøe, J.; Raaijmakers, T.C.; Schouten, J.J. Edge scour at scour protections around piles in the marine environment-Laboratory and field investigation. Coast. Eng. 2015, 106, 42-72. [CrossRef]

114. Pogoda, B.; Buck, B.H.; Hagen, W. Growth performance and condition of oysters (Crassostrea gigas and Ostrea edulis) farmed in an offshore environment (North Sea, Germany). Aquaculture 2011, 319, 484-492. [CrossRef] 